\title{
Antidumping and Safeguard Measures in the Political Economy of Liberalization: The Mexican Case
}

\author{
Luz Elena Reyes de la Torre* and Jorge G. González**
}

World Bank Policy Research Working Paper 3684, August 2005

The Policy Research Working Paper Series disseminates the findings of work in progress to encourage the exchange of ideas about development issues. An objective of the series is to get the findings out quickly, even if the presentations are less than fully polished. The papers carry the names of the authors and should be cited accordingly. The findings, interpretations, and conclusions expressed in this paper are entirely those of the authors. They do not necessarily represent the view of the World Bank, its Executive Directors, or the countries they represent. Policy Research Working Papers are available online at http://econ.worldbank.org.

* ler@sai.com.mx

** Jorge.Gonzalez@Trinity.edu

This paper was written for the World Bank. The authors acknowledge herein the valuable support and assistance given to this research by Emiliano Zubieta Medina, Jorge Sentíes Guerrero and Daniel Reyes Torres. 


\begin{abstract}
Mexico's creation and use of safeguard and antidumping processes to advance its liberalization illustrate three key points. First, the country was able to use the instruments without losing political control. In a period of crisis that threatened congressional approval of critical steps in the liberalization - brought on by currency overvaluation and recession, along with unexpected demands from the United States in the North American Free Trade Agreement (NAFTA) negotiations - the government applied a number of trade defense measures. Once the problems were addressed with adequate instruments the number of measures dropped drastically. The instruments had not been captured by protection-seeking interests.
\end{abstract}

Second, the country adopted a liberalization-accepting measure of international norms. An important innovation that Mexico made operational was the use within WTO rules of prevailing international prices as the measure of competition that industry was expected to meet. The WTO rules would also have allowed the use of other standards - as in traditional antidumping-using countries -- that impose less discipline. Moreover, the Mexican standard was consistent with the government-industry understanding that though Mexican industry would be protected against extraordinary circumstances it would be expected to face up to international competition.

Third, political judgment and political courage are essential. While mastery of the technical elements of a safeguard or antidumping investigation is mandatory, sustaining liberalization depends in significant part on the political skills to know when to emphasize the technical elements, when to rely more on the discretion the government retains under the rules, and on the courage to do it. 


\section{Table of Contents}

\section{Introduction}

I. Trade Liberalization and Contingent Trade Protection Instruments

1. Trade Liberalization and Economic Reform in Mexico

2. Mexico's First Antidumping Legislation and Its Adherence to the Antidumping Code as a Contracting Party

3. Contingent Trade Protection Instruments during NAFTA Negotiations
A. The Negotiation Context
B. Bilateral Panels and Agreements on Domestic Legal Reforms
C. Bilateral and Global Safeguards

II. The Amendment of the Antidumping Legal Framework in 1993 and its Ensuing Institutional Reform
1. The 1993 Foreign Trade Act
2. Institutional Reform: Creation of the Unit on International Trade Practices.
3. Attempts to Create a National Foreign Trade Commission

III. Antidumping and Safeguard Investigations and Their Final Determinations (1987-2003)
1. Requests, Initiations and Types of Investigations
2. Breakdown of Investigations by Country and Sector
3. Safeguard Cases: Almost Non-Existent? 


\section{Lessons: Case Studies}

1. The China Package and Multi-Country/Multi-Product Steel Cases

2. Mechanisms to Mitigate the Negative Effects of Antidumping Duties
A. Lesser Duty Rule
B. End-Use Certificates
C. Statements of Exclusiveness

3. The Unitary Approach to International Prices and the Causal Link: The Bond Paper Case

\section{Final Considerations}

\section{Bibliography}




\title{
Antidumping and Safeguard Measures in the Political Economy of Liberalization: The Mexican Case
}

\author{
Luz Elena Reyes de la Torre ${ }^{1}$ and Jorge $G$. \\ González²
}

\section{Introduction}

Since Mexico joined the General Agreement on Tariffs and Trade (GATT) in 1986 and until 1994, when the North American Free Trade Agreement (NAFTA) came into effect, mechanisms and institutions concerned with administering antidumping and safeguard proceedings were created and strengthened.

At first glance, the history of contingent protection mechanisms in Mexico appeared to be very contradictory to the actions adopted by Mexico to liberalize its trade and economy. Nevertheless, when its political economy is analyzed in depth, an indisputably logical connection is found together with an indissoluble link between the goals of trade liberalization and the strengthening of contingent trade protection institutions and mechanisms.

The Under-Secretary responsible for the legal and institutional reform that led to the full implementation of antidumping mechanisms in Mexico literally stated that "the monster was born only to protect the liberalization process.”3

1 Luz Elena Reyes de la Torre is a partner in SAI Consultores, S.C. She held the position of Associate General Director of the Unit on International Trade Practices (UPCI, according to its Spanish acronym) since its creation (1991-1996), and was in charge of negotiating the chapters on safeguards, dumping, subsidies and countervailing duties of the Mexican Free Trade Agreements with Costa Rica, Bolivia, Colombia and Venezuela. Since 1997, she has been a consultant representing companies in antidumping proceedings. Since 1999 she has participated as a panelist in the WTO Dispute Settlement Body.

2 Jorge G. González, a researcher and professor, is Chair of the Economics Department at Trinity University in San Antonio, Texas. In the last 15 years, he has published a great number of papers in specialized journals. His research deals with issues such as foreign investment, the economic impact of undocumented immigration, bibliometric studies on international economy, international trade between the United States and Latin American countries, the political economy of trade liberalization and of legislation on immigration, Mexican economy and Mexico's financial system.

3 Dr. Pedro Noyola Garagori was Under-Secretary of Foreign Trade and Investment between 1990 and 1994 at the Secretariat of Commerce and Industrial Development. He was responsible for promoting the creation of a specialized, strong and professional department in Mexico concerned with international best practices on antidumping, gaining the President's support to create the International Trade Practices Agency (Dirección General de Prácticas Comerciales Internacionales), later turned into the Unit on International Trade Practices (Unidad de Prácticas Comerciales Internacionales or UPCI), with a substantial budgetary allocation. Besides, he introduced radical reforms to the Foreign Trade Act (Ley de Comercio Exterior, in Spanish) in 1993. The official in charge of executing these projects was Dr. Álvaro Baillet, an economist and renowned administrator of the antidumping system, Head of the UPCI from 1991 to 1996. We are sincerely grateful to both for their support. 
This paper is divided into five sections that analyze the political and economic context in which Mexico adopted contingent trade protection instruments, the ensuing institutional reform, the economic history of the creation of institutions in charge of the administration of such instruments as well as the driving forces that played a relevant role in their development. In addition, the paper reviews and analyzes the investigations carried out by Mexican authorities, together with their determinations, and concludes by presenting case studies in order to draw lessons from this process. 


\title{
I. Trade Liberalization and Contingent Trade Protection Instruments
}

\begin{abstract}
"Mexico's accession to the GATT in 1986 meant the beginning of a gradual reduction of a highly-protected trade system which was, for 40 years, one of the pillars of industrial development. This first step towards trade liberalization consisted in the lowering of tariffs and the elimination of import licenses, accompanied by the creation of a system against unfair foreign trade practices. $", 4$
\end{abstract}

\section{Trade Liberalization and Economic Reform in Mexico}

In the early 1980s, the limitations of the import-substitution model became evident. This model, based on a protectionist policy, had given rise to an inefficient production structure, combined with monopolistic behavior and technological backwardness. State intervention was a constant feature in order to counteract the economy's inefficiencies that very often led to widespread, indiscriminate subsidies, exerting a heavy burden on public finances.

As shown in Table 1, in 1982 Mexico underwent the worst economic crisis of the model: on the one hand, the GDP dropped by $0.5 \%$ and, on the other, inflation rates rose from $28.7 \%$ in 1981 to $98.8 \%$ only one year later. In the same year, Mexico had such a severe balance-ofpayments crisis that the country became insolvent in the international financial markets. In the face of that crisis, the government decided to nationalize the banking system and impose a strict exchange control. Likewise, the balance-of-payments crisis obliged the government to maintain, and even reinforce, a highly protectionist trade policy to restrain imports and encourage a trade surplus in the shortest possible run in order to pay the foreign debt service; in fact, all imports were subject to import licenses. When external financing sources were no longer available, the country entered into a vicious circle of inflation and stagnation with severe implications for Mexico’s competitiveness and growth. ${ }^{6}$

4

Speech delivered by Dr. Raúl Ramos Tercero, Under-Secretary of Industry reporting to the Secretariat of Commerce and Industrial Development, at the opening of the seminar on Unfair Foreign Trade Practices and Emergency Measures, held in the Mexico City on September $6^{\text {th }} 1995$, and published in the journal El Mercado de Valores, Issue 11, November 1995.

According to the Mexican antidumping legislation in force, unfair international trade practices are defined as "the importation of goods under conditions of price discrimination or subsidization in the country of origin or source which cause or threaten to cause injury to the domestic industry.” Article 28 of the Foreign Trade Act..

$6 \quad$ Jaime Serra, 1994. 
Table 1 - Mexican Macroeconomic Indicators during the Economic Liberalization

\begin{tabular}{||c|c|c|c|c||}
\hline Year & $\begin{array}{c}\text { GDP Growth } \\
\text { (\% per year) }\end{array}$ & $\begin{array}{c}\text { Inflation } \\
\text { (\% per year) }\end{array}$ & $\begin{array}{c}\text { Observed nominal } \\
\text { exchange rate } \\
\text { (pesos/USD) }\end{array}$ & $\begin{array}{c}\text { CETES 28 days } \\
\text { interest rate } \\
\text { (average annual } \\
\text { rate) }\end{array}$ \\
\hline 1981 & 8.5 & 28.7 & 0.0262 & N.A. \\
\hline 1982 & -0.5 & 98.8 & 0.0963 & 44.408 \\
\hline 1983 & -3.5 & 80.8 & 0.1436 & 58.741 \\
\hline 1984 & 3.4 & 59.2 & 0.1920 & N.A. \\
\hline 1985 & 2.2 & 63.8 & 0.3683 & 61.590 \\
\hline 1986 & -3.1 & 105.8 & 0.9151 & 87.372 \\
\hline 1987 & 1.7 & 159.2 & 2.2097 & 96.048 \\
\hline 1988 & 1.3 & 51.7 & 2.2810 & 69.534 \\
\hline 1989 & 4.1 & 19.7 & 2.6410 & 44.993 \\
\hline 1990 & 5.2 & 29.9 & 2.9454 & 34.759 \\
\hline 1991 & 4.2 & 18.8 & 3.0710 & 19.278 \\
\hline 1992 & 3.5 & 11.9 & 3.1154 & 15.622 \\
\hline 1993 & 1.9 & 8.0 & 3.1059 & 14.931 \\
\hline 1994 & 4.5 & 7.1 & 5.3250 & 14.098 \\
\hline
\end{tabular}

*Nominal exchange rate to face foreign currency obligations (end of period).

**CETES 28 days interest rate for 1982 was based only on the September-December average; in the case of 1983, the January-July average was taken into account and for 1985, the February-December average was considered.

Source: INEGI, Banco de México.

It was in this context that the Mexican government decided to unilaterally liberalize its economy as the only way to increase its competitiveness and thus break the vicious circle of inflation and stagnation. The trade liberalization process began in 1983, but was strengthened from 1985 onward; maximum tariffs, as high as $100 \%$, were lowered to $20 \%$ in only three years. The weighted average tariff dropped from $13.3 \%$ to $6.2 \% .^{7}$ In 1985 , of a total 5,219 tariff items subject to import permits at the beginning of the year, 3,064 were exempted from such a requirement. The value of imported goods subject to licenses dropped from $83 \%$ to $37 \%$. The impact of such phasing out of trade protection mechanisms during the period was

Broadly speaking, 5 tariff levels were established based on the following criteria: $20 \%$ for consumer goods; $15 \%$ for intermediate goods; $10 \%$ for raw material and $5 \%$ or $0 \%$ for products either insufficiently produced or not manufactured at all at the domestic level or by agreement with the private sector, SECOFI, 1993. 
mitigated by an exchange policy whereby the exchange rate was significantly devalued from 368 to 915 pesos per US dollar — from the end of 1985 to the end of $1986{ }^{8}{ }^{8}$

At that time, the Mexican government realized that, given the significant trade liberalization process unilaterally undertaken, it was no longer reasonable to remain outside the General Agreement on Tariffs and Trade (GATT), ${ }^{9}$ since this prevented the country from taking advantage of the commercial benefits granted to its Members through tariff preferences. Thus, Mexico joined the GATT in $1986 .{ }^{10}$

Within the GATT, Mexico stated its commitment to further eliminate import licenses ${ }^{11}$ and to reduce maximum tariff levels, but was authorized to put in place a system of antidumping and countervailing duties.

Table 2 - Comparative Tariff Structures in Selected Years

\begin{tabular}{||l|c|c|c||}
\hline \multicolumn{1}{|c|}{ Concept } & $\mathbf{1 9 8 2}$ & $\mathbf{1 9 8 5}$ & $\mathbf{1 9 9 2}$ \\
\hline Maximum Tariff & 100 & 100 & 20 \\
\hline Weighted Average Tariff & 16.4 & 13.3 & 11.4 \\
\hline Tariff Dispersion & 24.8 & 18.8 & 4.5 \\
\hline
\end{tabular}

Source: SECOFI, 1993.

\section{Mexico's First Antidumping Legislation and Its Adherence to the Antidumping Code as a Contracting Party}

In line with its decision to join the GATT, Mexico began the legal and institutional reforms required at the domestic level to support governmental actions adopted as a result of the new development model and its recent international commitments. In this context, in January 1986 the first antidumping legislation was enacted: the Law Regulating Article 131 of the Political Constitution of the United Mexican States on Matters of Foreign Trade (hereinafter, the Law Regulating Article 131). In November 1986, the Regulations against unfair trade practices in

On November $26^{\text {th }} 1985$, the GATT Director-General was informed about the Mexican government's decision to initiate the process of accession to the GATT, Foreign Trade Department (Gabinete de Comercio Exterior) (1986).

Mexico formally acceded to the GATT in August 1986. This accession, ratified by the Senate of the Republic in September 1986, came into force in November 1986. 
international trade (hereinafter, the Regulations) were promulgated, and in 1987 the first request to initiate an antidumping proceeding was filed. It involved the case of caustic soda imported from the United States. ${ }^{12}$

The application of antidumping and safeguard instruments in Mexico was initially within the purview of administrative areas having other responsibilities as well; in fact, the first investigations were conducted by the agency concerned with exchange control in the General Trade Bureau (Dirección General de Comercio), under the Secretariat of Commerce and Industrial Development (Secretaría de Comercio y Fomento Industrial). ${ }^{13}$

The antidumping proceedings provided for in the Law Regulating Article 131 and its Regulations were both elementary and limited. By the end of the 80s, Mexican authorities deemed it necessary to amend antidumping-related provisions.

One of the most controversial issues of the Law Regulating Article 131 was the possibility for antidumping duties to be applied only five days after a request was filed with the relevant authorities. ${ }^{14}$ The time frame granted to respondents was very short, and provisions related to proceedings were not clear enough. All of these factors combined to give rise to a high degree of uncertainty among the parties to the proceedings, allowing room for authorities to act on a discretionary basis.

In fact, during the meetings held by Mexico with the working party appointed under the GATT in order to analyze its application for accession ${ }^{15}$ from April to July 1986, one of the first questions posed was how Mexico could possibly reach provisional affirmative

This elimination was not subject to any scheduling or specific date, Foreign Trade Department (Gabinete de Comercio Exterior) (1986), p. 13.

In an interview, Héctor Vázquez Tercero, an official commissioned with administering the first antidumping law in Mexico and conducting the first antidumping investigation in 1987, pointed out that the government was absolutely convinced that as the country's development model had changed, a system was required to effectively fight unfair international trade practices for the benefit of domestic manufacturers. Furthermore, he said that since the enactment of the Law and its Regulations, the government itself promoted the use of this system because its instruments were deemed necessary.

Héctor Vázquez Tercero, personal interview.

Article 11 of the Law Regulating Article 131: “...Having satisfactorily received the claim to which the preceding article makes reference, the Secretariat of Commerce and Industrial Development shall issue, within a period of five working days, a provisional resolution establishing the countervailing duty to be applied, if appropriate, and shall further investigate the unfair international trade practice subject of said resolution, which shall become effective one day after its publication in the Official Gazette of the Federation.” 
determinations of unfair international trade practices within only five working days of the filing of a request for investigation. ${ }^{16}$

Another aspect of the Law Regulating Article 131 that was objected within the GATT working party was that evidence of injury was not compulsory. ${ }^{17}$ The GATT working party concluded that some of its legal provisions were not completely in line with GATT principles and recommended that Mexico subscribe the Antidumping Code (ADC) ${ }^{18}$ Mexico decided to become a signatory of the Tokyo Round Antidumping Code in 1988.

\section{Contingent Trade Protection Instruments during NAFTA Negotiations}

\section{A. The Negotiation Context}

In 1988, starting with the inaugural speech delivered by the newly elected President of the Republic, a modernizing project began to take shape based on the furthering of the economic and trade liberalization process.

In 1988, 65\% of Mexican trade was with the United States. Sectoral agreements, mainly those reached in the textile and steel industries, as well as the Generalized System of Preferences, represented only limited trade and investment mechanisms between both countries. Furthermore, the time frames of sectoral agreements as well as the uncertainty as to their extension were no guarantee of the permanent access of Mexican products to the US market. ${ }^{19}$

In June 1990, the Mexican and US Presidents issued a joint communiqué stating that the best vehicle for increasing trade and investment flows between both countries was the signing of a

15 Report by the working party on the terms of the accession of Mexico, Foreign Trade Department (Gabinete de Comercio Exterior), 1986.

Ibid., p. 53.

It was deemed compulsory, as an exception, when Mexico signed bilateral agreements including a reciprocity clause.

Op. cit.

Arriola (1994), Documentos básicos del TLCAN. On his official visit to the United States in October 1989, President Salinas stated in his presentation of October $4^{\text {th }}$ before the two Houses of Congress that for Mexico to continue to be "one of the most open economies at the international level, reciprocity is needed. In a framework of understanding and cooperation, there should not be any non-tariff barrier either preventing or hindering the flow of goods between 
Free Trade Agreement. ${ }^{20}$ On June $12^{\text {th }} 1991$, formal negotiations were started with a view to concluding the NAFTA among Mexico, the United States and Canada. ${ }^{21}$

\section{B. Bilateral Panels and Agreements on Domestic Legal Reforms}

At the beginning of NAFTA negotiations, Canada proposed that antidumping laws should no longer be applied among the countries that would be part of the new North American market. While Mexico supported Canada's proposal, the United States rejected it categorically. ${ }^{22}$ The Mexican and Canadian positions were in full agreement, since exporting industries in both countries had been adversely impacted by antidumping instruments applied by the United States, a world leader in their use.

The United States was inflexible in its determination not to amend its antidumping legislation and practice as long as the Uruguay Round was not concluded. While the United States agreed to appoint two working groups ${ }^{23}$ to analyze the possibility of implementing a substitute system during the transition, in practice there has been no concrete results ten years after the NAFTA’s implementation.

In this context, the core of the trilateral negotiation on unfair international trade practices was the incorporation of a system of binational panels specifically engaged in reviewing final determinations on antidumping and countervailing duties made by competent authorities in each member country, as it was later established in NAFTA Chapter XIX.

For Mexico, another important aspect of NAFTA negotiations was related to its commitment to amend its domestic statutes and regulations. ${ }^{24} 25$ It should be noted that Mexico had already

the United States and Mexico. Our country has almost eradicated them entirely; however, we still face them in the United States (...) we want a bilateral agreement that should aim at the collapse of trade barriers, sector by sector.” Communiqué dated June $10^{\text {th }}, 1990$.

NAFTA negotiations were formally initiated at a meeting attended by trade representatives of the three countries in the city of Toronto, Canada: the Mexican Secretary of Commerce and Industrial Development, Dr. Jaime Serra Puche, the Canadian Minister of Industry, Science and Technology and Minister of International Trade, Michael Wilson, and the US trade representative, Carla Hills; Zabludovsky, p. 115.

$22 \quad$ Leycegui 2000, p. 579.

23 To that end, a Working Group on Trade and Competition and another on Antidumping and Countervailing Duties were created; Leycegui 2000, p. 580.

24 The amendments to which the United States and Canada committed themselves were but adjustments needed for the binational panel system, as prescribed in Chapter XIX.

25 Annex 1904.15, Schedule of Mexico in SECOFI, 1993, Tratado de Libre Comercio con América del Norte, Official NAFTA text, p. 546. 
made the decision to introduce the amendments agreed upon in early 1991; therefore, it would be wrong to conclude that Mexico was forced by its NAFTA trade partners to set up transparent procedures to apply antidumping and safeguard measures. Actually, this decision was adopted at the domestic level as a key component of its economic liberalization process.

\section{Bilateral and Global Safeguards}

While in the case of antidumping measures there was, to a certain degree, a legal framework common to all three member countries, the ADC-, in the field of safeguards there was no specific multilateral agreement, nor was there any regulation to guide their application in Mexico. The only reference in common was the provisions of Article XIX of the GATT.

In parallel with NAFTA negotiations, negotiators of the Uruguay Round were discussing which provisions to include in one of the new Agreements of the World Trade Organization (WTO), the Safeguards Agreement. However, at that time there were still more disagreements than agreements over safeguard actions at the multilateral level; consequently, during the trilateral negotiations it was impossible to predict the final outcome of the multilateral agreement. Hence the need to introduce a detailed administrative procedure that should govern the trade partners' actions while trying to avoid any inconsistency with the Round's final conclusions.

Under the NAFTA, two kinds of safeguard measures were negotiated: bilateral and global. Bilateral actions comprised those applied exclusively between two NAFTA partners. On the other hand, emergency global actions were those taken pursuant to GATT Article XIX. With

regard to global actions, “exclusion” clauses among trade partners as well as compensations for the affected Party were included. The agreement reached on these topics is reflected in NAFTA Chapter VIII. 


\section{The Amendment of the Antidumping Legal Framework in 1993 and its Ensuing Institutional Reform}

\section{The 1993 Foreign Trade Act (Ley de Comercio Exterior, in Spanish)}

During 1992 and the first months of 1993, Mexico conducted a comprehensive public discussion on the draft of the future Foreign Trade Act, published in the Official Gazette of the Federation (Diario Oficial de la Federación or DOF) in July 1993, prior to NAFTA's approval $^{26}$ and the conclusion of the Uruguay Round's final agreements. This schedule was due to Mexico's urgency to have a foreign trade legal framework in place to provide support to the new proceedings and institutions that were being applied and created since 1991 in line with its new economic and trade policy model. The Regulations of the Foreign Trade Act were published in the DOF on December $12^{\text {th }}, 1993$.

This new law introduced substantial changes in the first Mexican antidumping legal framework, the institutional structure, and the administrative proceedings, it also incorporated substantive provisions in conformity with the area's state of the art. The peculiarities of the new proceedings as well as the complexity of investigations on unfair practices and safeguard actions posed a real challenge for the Mexican procedural tradition.

Among the modifications introduced in domestic laws, WTO-Plus provisions are to be highlighted. Resulting from NAFTA negotiations, these provisions were aimed at bringing transparency to proceedings and offering equal access to information and defense to all of the parties concerned. The following can be mentioned, inter alia: (i) technical information meetings are to be held; (ii) confidential information shall be made available to the accredited legal representatives of the parties; (iii) a mechanism for the sharing of documents submitted to the competent authority among all interested parties; and (iv) the obligation to keep transcripts and records of meetings or hearings before the relevant authority, as well as of any external consultancy requested by such authority in relation to the proceedings.

In August 1992, NAFTA negotiations were concluded. Prior to the enactment of the NAFTA by the legislative bodies in the three signatory countries, presidential elections were held in the United States, as a result of which William Clinton took office. The newly elected president conditioned the enactment of the NAFTA to the conclusion of parallel agreements on labor and environmental cooperation. It was only in November 1993 that the legislative approval of the NAFTA was concluded in the three countries. 
With regard to proceedings, the Foreign Trade Act and its Regulations explained in detail the methodology to be applied thereafter in compliance with the Antidumping Code, the progress made in the Uruguay Round, the commitments made by Mexico under the NAFTA, and the experience gained by the new administrative body specialized in antidumping measures.

Pursuant to the Foreign Trade Act, no antidumping duties were allowed to be imposed upon the initiation of an investigation ${ }^{27}$ and the time limit for the parties to appear was set to 30 working days, a term that could be extended on justified grounds. The new time frames were consistent with those set forth in the ADC, and proceedings were thus extended from a maximum term of six months to almost one year (260 working days).

Additionally, the Act specified that the authority's decisions were to be transmitted to all the parties concerned on the same day they were $\operatorname{taken}^{28}$ and that communications between competent authorities and interested parties could be made by any direct means, such as personally at their domicile, by registered mail with acknowledgement of receipt, specialized messenger service or by electronic means, such as by fax. ${ }^{29}$

This Foreign Trade Act formalized the searches for the purpose of verification established with the new administrative practice. An innovating aspect of the Mexican practice was that from 1991 onwards, besides those conducted to investigated exporters, verification visits could be conducted also to investigate domestic producers or to determine injury in all antidumping investigations initiated by the authority. ${ }^{30}$ Determinations of injury had a twofold purpose: to make domestic producers become aware of the fact that the new antidumping institutions created in the country were to be taken seriously and to show countries under investigation that determinations by authorities would be both impartial and supported by evidence.

\footnotetext{
This amendment is the first item in NAFTA's "Schedule of Mexico".

Article 53 of the Foreign Trade Act.

In its first report, the UPCI stated that thanks to the fact that notifications by electronic means were allowed, it had been possible to send more than one hundred notifications to parties interested in the multi-country/multi-product steel case (1993), SECOFI 1997.

30 This practice was implemented in many countries that were adopting antidumping mechanisms at that time on the basis of the Mexican experience. The experience was disseminated to other countries through the UPCI's training programs offered to officials.
} 
The Foreign Trade Act instituted the technical information meetings. ${ }^{31}$ Under the new Act, the parties can have access to details not included in the authorities' public resolutions with regard to the method used in determining the margins of dumping, injury or threat of injury and the arguments concerning causality. ${ }^{32}$

Pursuant to the new Act, public hearings were to be held in all antidumping and safeguard proceedings. ${ }^{33}$ Mexican authorities were convinced that public hearings would introduce greater transparency and objectivity; therefore, even though the obligation under NAFTA explicitly focused on safeguard proceedings, it was extended to all types of proceedings related to contingent trade protection.

With reference to antidumping duties, the modification of their nature stands out. ${ }^{34}$ According to the Foreign Trade Act, countervailing duties were to be considered revenue within the meaning of Article 30 of the Federal Tax Code. In the previous law (the Law Regulating Article 131), countervailing duties were regarded as taxes, which is the reason why they were often challenged on the grounds of unconstitutionality.

Another reform to which Mexico committed itself during NAFTA negotiations involved ensuring access to confidential information related to the proceedings. This was also intended to increase transparency and objectivity in the proceedings, by giving the parties better opportunities for defense.

For the first time in Mexican legislation history, the Foreign Trade Act incorporated a procedure specifically designed to apply safeguard measures. Since the Act was drafted prior to the conclusion of the Uruguay Round, so that the final agreements on this issue were not yet

31 Commitment made by Mexico under the NAFTA.

32 In recent years, this obligation has turned into a mere administrative formality, not contributing to the proceedings' transparency. In the early years of the Act's implementation, authorities used to give to the parties concerned documents that described the specific method used for injury determination by means of approximate figures or indexes to preserve the confidentiality of the information. The agency also supplied, upon request, the SAS programs developed by the authorities for the specific estimation of dumping margins in each company. At present, the only information an exporting company receives is that which the company itself has previously submitted; the other companies are denied SAS programs or the information about the method used for injury determination purposes, alleging confidentiality reasons. Meetings only serve the purpose of repeating the content of provisional or final determinations.

Article 81 of the Foreign Trade Act.

In Mexican legislation, the term "countervailing duties” is used to refer to either antidumping or countervailing duties. 
known, it adopted various provisions taken from the drafts of the Safeguards Agreement (SA) and others derived from NAFTA negotiations. However, the final drafting of the Safeguards Agreement underwent modifications and several of its final provisions turned out to be less stringent than the ones laid down in the Foreign Trade Act.

\section{Institutional Reform: Creation of the Unit on International Trade Practices}

By the end of 1990, the Secretariat of Trade and Industrial Development (SECOFI, in Spanish) submitted to the consideration of the President an initiative to create an administrative body specialized in examining requests for applying contingent trade protection measures. The reason for its creation and strengthening was to ensure a technical, professional, non-discretionary, and disciplined administration of these mechanisms "so that they should neither interfere with nor revert the trade liberalization process.”35

In January 1991, the Mexican government created the first body specifically concerned with antidumping issues, namely the International Trade Practice General Bureau (Dirección General de Prácticas Comerciales Internacionales or DGPCI). ${ }^{36}$ It was commissioned with the task of strictly applying antidumping instruments when so justified, while preventing the antidumping system from becoming an obstacle to the trade liberalization efforts undertaken by Mexico.

The DGPCI's capacity was reinforced when a practically new staff of highly qualified professionals was hired. Intensive training was given to new members engaged in investigations. As soon as the DGPCI was created, its staff conducted a broad comparative

35 Interview with Dr. Pedro Noyola Garagori, who submitted to the consideration of the President of the Republic the project to create a specialized department engaged in contingent protection instruments and who was responsible for drafting the new Foreign Trade Act. Dr. Noyola further explained that assigning contingent protection to a lowprofile, non-technical, discretionary and unprofessional area was too high a risk for the opening of the economy, since that decision might open up the path for anti-liberalization or protectionist forces and for the old guard within the government.

36 The first antidumping cases were filed with the area concerned with exchange controls, which in 1987 was still under the purview of the Commerce Bureau (Dirección de Comercio), reporting to the Under-Secretariat of Foreign Trade (Subsecretaría de Comercio Exterior), which was part of the SECOFI. Between 1986 and 1990, antidumping proceedings were initiated in various departments busy with other activities as well. In 1990, the Bureau of Countervailing Duties (Dirección de Cuotas Compensatorias) was created within the General Bureau of Foreign Trade Services (Dirección General de Servicios al Comercio Exterior) of the SECOFI. 
study of the antidumping systems in force in the United States and Canada, countries with which the first contacts on this topic would soon be established in the context of a potential trilateral trade negotiation.

This new entity signed cooperation agreements with the agencies responsible for administering antidumping systems in the United States and Canada for the technical training of its staff, who visited those countries on several occasions to become more acquainted with their procedures and methodologies. The European and Australian models were also studied. Preliminary actions were taken to design a new regulatory framework, leading to the enactment of the Foreign Trade Act and its Regulations in 1993.

Furthermore, an intensive dissemination campaign was launched targeting Mexican productive sectors. Its aim was to inform them about the existence of such new contingent protection instruments, while stressing the strict analysis and methodology to be applied by competent authorities. The campaign sought to raise credibility in the new institutions, the activities of which relied on its highly-qualified professionals and the transparency of the proceedings. ${ }^{37}$ As part of this process, the SECOFI decided to hire the services of an accounting firm, selected among the most important ones in Mexico, in order to assist its new antidumping officials in their verification visits and thus validate the information gathered for the proceedings.

The institutional strengthening was furthered in 1993 when the Unit on International Trade Practices (UPCI, in Spanish) was created to replace the DGPCI. The UPCI was the administrative unit responsible for determining dumping margins, injury or threat of injury and their causal relation as well as antidumping or countervailing duty rates. Its structure, composition, and size were substantially different from those of any other Federal Government agency of the time. While the DGPCI had 18 staff members at the time of its creation, the UPCI was established with 120 highly qualified professionals. Many operational and support positions were eliminated, while field management areas were enlarged. Additionally, five associated management agencies were created-the Technical-Legal 
Management Agency, the Dumping and Subsidies Investigation Management Agency, the Injury and Safeguards Investigation Management Agency, the Accounting and Financial Analysis Management Agency and the International Legal Proceedings Management Agency.

The UPCI's budget allocation grew substantially and it soon became the administrative unit with the largest qualified staff, outperforming any other department of the Secretariat in terms of both personnel and budget allocation.

The role of the competent authorities was both strengthened and diversified. In addition to conducting investigations, the UPCI would act as a technical advisory unit, cooperate in drafting any amendment to the Foreign Trade Act, support the SECOFI's determinations submitted before dispute settlement bodies, and offer technical and legal assistance to Mexican exporters who were under investigation in a foreign country for unfair practices or safeguard measures. ${ }^{38}$

The activities undertaken by this new entity - concerned with the administration of an instrument so distrusted in many important countries in the world because of its protectionist use at a time in which Mexico was committed to policies reinforcing its trade and economic liberalization process - were ambivalent and even contradictory. This can be inferred from officials’ communications as well as from governmental programs of that period. ${ }^{39}$

In this context, the Program for Industrial and Foreign Trade Policy (Programa de Política Industrial y Comercio Exterior or PROPICE) clearly shows the Government's continuing concern arising out of the conflict between the greater use of antidumping instruments and the trade policy objectives. Since the liberalization process had been undertaken with the key objective of increasing the manufacturing sector's competitiveness, the government feared the negative impact that antidumping measures might have on capital and intermediate goods.

SECOFI 1997. Informe de Labores UPCI 1991-1996, SECOFI.

While the National Development Plan 1995-2000 set forth that one of its key guidelines on foreign trade was to "penalize with utmost rigor and efficiency any unfair trade practice affecting our manufacturers," the main objectives of the antidumping policy under the Program for Industrial and Foreign Trade Policy (PROPICE) revealed the government's concern over the potential conflict between contingent protection measures and the new development model for the country: “...in designing our policy against unfair international trade practices, we should take into account that applying countervailing or antidumping duties may severely affect our manufacturers' competitiveness in the coming years” on account of the substantial increase of investigations filed. 
Nonetheless, as in 1991, when it was decided that the best alternative was to create a strong institution engaged in the administration of those measures, the new government decided once again that the best way to guarantee the protection of the trade liberalization process was to strengthen its institutions and mechanisms. ${ }^{40}$ The main guidelines can be summarized in the notions of procedural transparency and operational capacity:

Owing to the inevitable complexity that investigations on unfair practices entail, the precise enforcement of relevant legislation depends most especially on the resources available to the investigation unit. This leads to the need to prevent the turnover and encourage the specialized training of its management, technicians and administrative staff, as well as to strengthen its power to take action. (Emphasis added.) ${ }^{41}$

\section{Attempts to Create a National Foreign Trade Commission (Comisión Nacional de Comercio Exterior)}

In 1994, the UPCI's structure and role were reinforced once again through a greater resource allocation. In that year, the Secretariat for Finance and Public Credit (Secretaría de Hacienda y Crédito Público or SHCP) approved the new budget and structure for the UPCI, even though such changes meant a deviation from applicable federal rules. This exception was accepted by the SHCP provided it was a transition to get past the elections, so that at the beginning of the new administration this body could become a decentralized agency. Thus, the government had set the administrative and budgetary conditions to create in 1995 a decentralized body that would be known as the National Foreign Trade Commission (CNCE, in Spanish).

The CNCE was conceived as an independent agency, with its own budget appropriation, and a decision-making team. Apart from the UPCI's role in proceedings related to contingent trade measures, ${ }^{42}$ this Commission would perform similar duties as those of the US International Trade Commission — namely to conduct studies on industrial competitiveness vis-à-vis the

On many occasions, high-ranking officials stated that the trade defense system was a necessary evil, but that it should be kept under strict control through its professionalization and the development of its methods and regulations.

$41 \quad$ SECOFI 1995, op. cit. 
international market, to monitor products sensitive to international competition, and to do research on the economic impact of trade agreements, among others.

The purpose for creating this Commission was to ensure that proceedings against unfair international trade practices would be basically technical and not subject to political pressure. $^{43}$ This institutional and decision-making framework was thought to be the only way to ensure an accurate, transparent, and objective application of contingent protection instruments and to avoid their discretionary or protectionist use. Another purpose of this institutional structure was to foster a career for civil servants, thus preventing highly qualified human resources from becoming vulnerable to the political fluctuations inherent to the federal public administration.

The private sector supported and promoted the creation of the CNCE for very different reasons from those held by the federal government. The local industry believed that UPCI's decisions were strongly influenced by the liberalization policy and the international trade agenda. Consequently, if decisions on contingent trade policies were to become independent from the SECOFI, protection measures would be applied more frequently and effectively for the benefit of the local manufacturing sector.

The crisis precipitated by the change of government in 1994, the devaluation of the local currency, and the serious problems affecting the Mexican economy in that period prompted a radical change of priorities; in this context, the CNCE lost its precedence. The new Secretary of Commerce thought it a danger to trade liberalization to strengthen and to remove from the sphere of the SECOFI — the Secretariat most committed to trade liberalization — any decision related to contingent trade protection; consequently, he refused to support the project. ${ }^{44}$

The proposal was to keep a unified system, i.e. that the same body should be in charge of determining both dumping and subsidies and injury or threat of injury to the national industry.

43 The UPCI itself had made use of this tool yielding to political pressure. However, given the profile of its officials and the government's commitment to the economic and trade liberalization process, the discretionary use of those instruments was done in such a way to minimize their effects on the trade liberalization objectives (see 1993 determinations on the China package and the multi-country/multi-product steel cases under section IV of this Chapter).

44 This attitude clearly reflects the discretionary bias in authorities' decisions. It is evident that this discretionary power was used for the sake of the liberalization process in the years of its consolidation, but it also reflects its inherent risks, since it can be used for the opposite purpose. A case in point to show its ill-use was the fructose investigation, the Mexican antidumping determination most strongly questioned and challenged to date.
} 


\section{Antidumping and Safeguard Investigations and Their Final Determinations (1987-2003)}

\section{Requests, Initiations, and Types of Investigations}

Between 1987 and 2003, the Mexican government initiated 262 investigations, of which 92\% were caused by dumping practices and $7 \%$ by subsidies, while only $1 \%$ of the cases initiated until December 2003 were caused by safeguard measures ${ }^{45}$ (Table 3 below). These data only take into account initiations of new investigations and exclude proceedings derived from original investigations, such as reviews of final determinations or sunset reviews. Proceedings are quantified by product-country pairs following the WTO criterion, i.e. a resolution to initiate an investigation on corrugated rods against imports from Brazil and Spain is taken as two investigations. The only exception to the rule is the so-called “China Package”.

Table 3 - Antidumping, Anti-Subsidy, and Safeguard Proceedings Initiated in Mexico, 1987 - 2003

\begin{tabular}{||l|c|c|c|c|c||}
\hline $\begin{array}{c}\text { Type of } \\
\text { investigation }\end{array}$ & $\begin{array}{c}\text { Number of } \\
\text { investigations }\end{array}$ & $\begin{array}{c}\text { Percentage vis- } \\
\text { a-vis the total } \\
\text { number of } \\
\text { investigations }\end{array}$ & $\begin{array}{c}\text { Number of } \\
\text { concluded } \\
\text { cases }\end{array}$ & $\begin{array}{c}\text { Number of } \\
\text { concluded cases } \\
\text { with measures in } \\
\text { force in } 2002\end{array}$ & $\begin{array}{c}\text { Percentage of } \\
\text { concluded cases, } \\
\text { with measures } \\
\text { currently in effect }\end{array}$ \\
\hline Dumping & 240 & $91.6 \%$ & 216 & 74 & $34.26 \%$ \\
\hline Subsidies & 19 & $7.2 \%$ & 18 & 7 & $38.89 \%$ \\
\hline Safeguards & 3 & $1.1 \%$ & 3 & 1 & $33.33 \%$ \\
\hline Total & 262 & $100.00 \%$ & 237 & 82 & $34.18 \%$ \\
\hline
\end{tabular}

Source: UPCI and 2003 DOF data.

According to the information available, $73 \%$ of the requests for investigation filed are admitted by the competent authority. ${ }^{46}$ Eighty-six percent of the investigations initiated lead to the application of provisional duties, while 58\% concluded with the imposition of antidumping or countervailing duties. These percentages have apparently increased with the passing of

45 The statistical annex includes a detailed list of all the investigations initiated in that period.

46 This percentage corresponds to the 1992-2002 period, of which records of rejections are available. Prior to that date, any request rejected by the authority on the grounds of non-compliance with formalities or irrelevance was notified to the interested party only. 
time: in the 1987-1995 period, only $46 \%$ of investigations had resulted in antidumping or countervailing duties. ${ }^{47}$

The last column in Table 3 above shows that in 2002 34\% of concluded cases had antidumping or countervailing duties in force. This percentage, far lower than the 58\% previously mentioned, is due to the fact that after annual administrative or sunset reviews some duties are eliminated. Given the years gone by since the system has been implemented, a great part of its current activity focuses on proceedings other than new investigations, as shown by the UPCI's statistics on resolutions (last two columns in Table 4).

Table 4 - Resolutions Regarding Unfair Practices and Safeguards, 1987-2002

\begin{tabular}{|c|c|c|c|c|}
\hline Year & Rejections & $\begin{array}{c}\text { Investigations } \\
\text { initiated }\end{array}$ & $\begin{array}{c}\text { Special } \\
\text { proceedings }^{1}\end{array}$ & Other $^{2}$ \\
\hline 1987 & N.A. & 18 & $\ldots$ & $\ldots$ \\
\hline 1988 & N.A. & 11 & $\ldots$ & $\ldots$ \\
\hline 1989 & N.A. & 7 & $\ldots$ & $\ldots$ \\
\hline 1990 & N.A. & 12 & $\ldots$ & $\ldots$ \\
\hline 1991 & N.A. & 9 & $\ldots$ & $\ldots$ \\
\hline 1992 & 8 & 26 & $\ldots$ & $\ldots$ \\
\hline 1993 & 12 & 83 & $\ldots$ & $\ldots$ \\
\hline 1994 & 16 & 26 & $\ldots$ & $\ldots$ \\
\hline 1995 & 2 & 4 & 8 & 1 \\
\hline 1996 & 6 & 4 & 16 & 5 \\
\hline 1997 & 5 & 7 & 7 & 1 \\
\hline 1998 & 0 & 11 & 6 & 16 \\
\hline 1999 & 10 & 11 & 4 & 13 \\
\hline 2000 & 5 & 5 & 10 & 22 \\
\hline 2001 & 7 & 5 & 13 & 16 \\
\hline 2002 & 0 & 12 & 10 & 9 \\
\hline 2003 & N.A. & 11 & N.A. & N.A. \\
\hline Total & 71 & 262 & 74 & 83 \\
\hline
\end{tabular}

1/ They include product coverage, benefit extension, new exporters and anti-circumvention.

2/ Reference price and duty elimination and review.

Source: Informe Anual de Labores 2002, UPCI and DOF. 
Fifty-five percent of initiations in Mexico took place in only four years, from 1991 to 1994, the most intense period of trade negotiations and economic reform. In that period, Mexico became one of the five most active countries in the use of antidumping instruments in the world, together with the United States, Australia, Canada and the European Union.

Figure 1 - Initiations in Mexico, 1987-2003

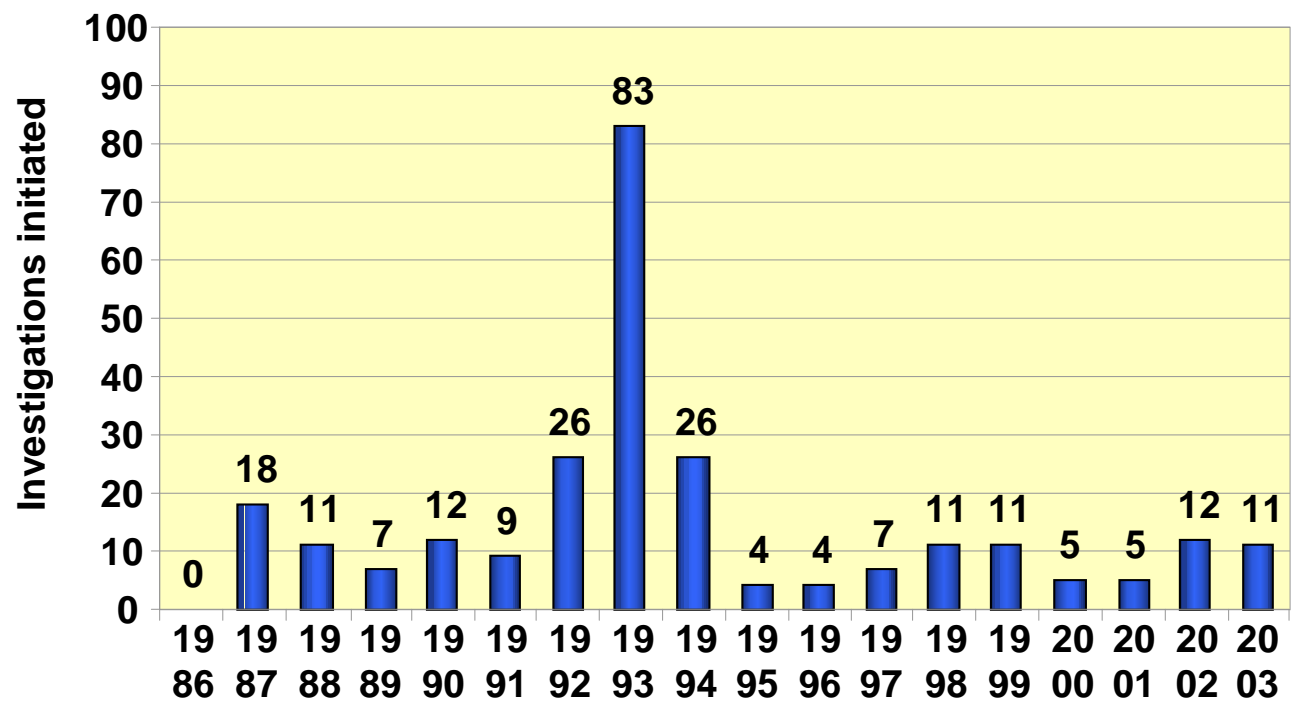

Source: 1986-2002, UPCI; 2003, DOF.

Figure 1 shows that antidumping proceedings in 1993 reached an unprecedented figure, never recorded again in the country. Of the 83 initiations reported in that year, 53\% corresponded to two investigation groups or packages: the first one against imported goods from China, the socalled "China Package"; the second one, against steel products from several countries, proceedings known as "multi-country/multi-product steel cases.”

Between 1992 and 1993, the pressure exerted upon the Mexican government by sectors significantly affected by the trade liberalization process was so strong that it began to jeopardize the credibility of the new trade defense institutions. This was threatening the national consensus reached for the conclusion and approval of the NAFTA, other international negotiations, as well as several economic reforms underway.

In its first activity report, the UPCI explained that the behavior of the economy had a direct impact upon the evolution and development of the system. "The most active years were those in which the reduction of the real exchange rate of the peso as well as the economic growth led 
to an increase in the volume of imports."48 Figure 2 shows two variables: one represents the behavior of the number of initiations and the other, the margins of over/undervaluation of the Mexican peso.

Figure 2 - Investigations Initiated and Over/Undervaluation Margins of the Exchange Rate in Mexico, 1987-1997

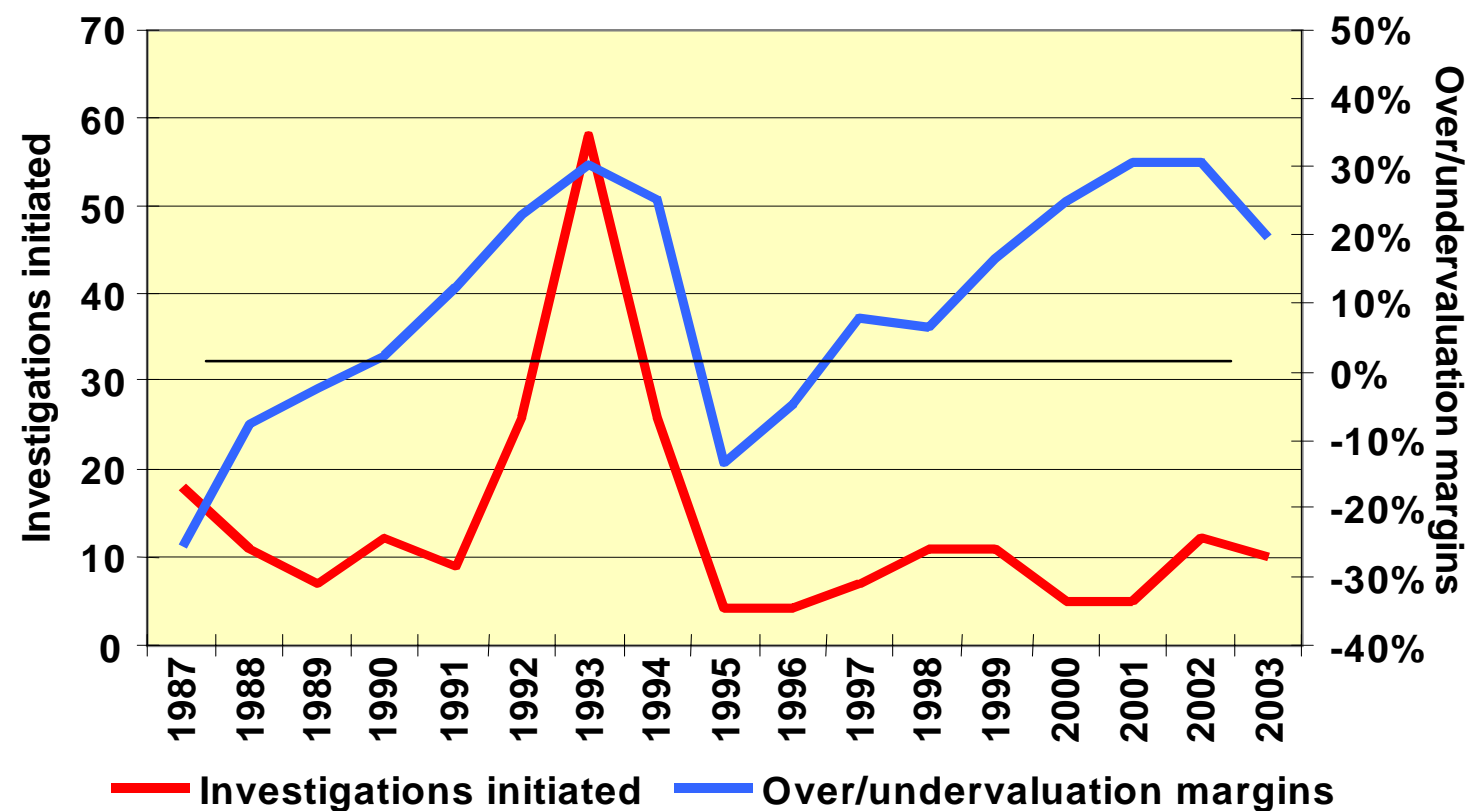

Source: Estimated over/undervaluation margins, based on Banco de México’s information for 1989-1990 and on the Purchasing Power Parity (PPP); investigations initiated in 1987-1997, UPCI.

Even though Figure 2 above seems to indicate that the antidumping activity increase in Mexico in the 1991-1997 period could be largely explained by the behavior of the real exchange rate, other political and economic events or circumstances taking place in the country contributed to the expansion of this activity as well. 
According to reports by the SECOFI and PROPICE, ${ }^{49}$ the increase in antidumping investigations resulted from other economic events taking place at the time Mexican trade was further liberalized —namely fluctuation of some goods in international markets, recession periods in industrial countries and other events that led to the restructuring of the world trade, forcing some countries to look for new export markets and to compete under unfair trade conditions. $^{50}$ Figure 3 illustrates how some major economic and political events occurred simultaneously in Mexico during the peak of antidumping activity.

Figure 3 - Investigations Initiated in Mexico, 1987-2003

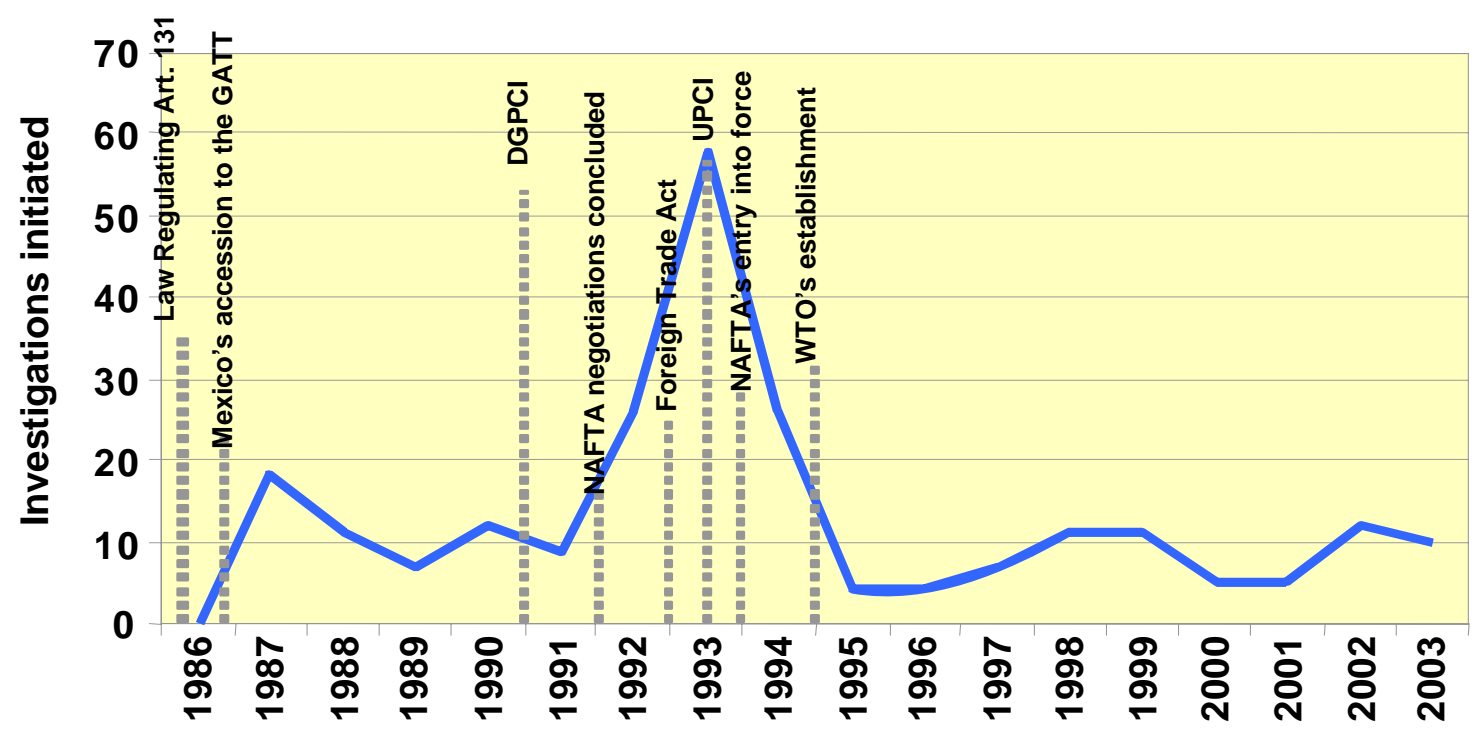

Source: 1987-1992 and 1994-2002, UPCI; 1986, 1993, 2003, DOF.

\section{Breakdown of Investigations by Country and Sector}

Mexico has filed proceedings against 49 countries, ${ }^{51}$ three of which account for $54 \%$ of all the investigations. The United States comes in first place (27\% of all initiated cases), followed by China (18.3\%), and Brazil (10\%) (see Table 5 below). This ranking changes when the analysis

According to the PROPICE, there were three decisive factors that account for antidumping activity in Mexico in the 1991-1994 period: (i) the effect of the international economic cycle on the raw material markets and the expansion in the related industries of surplus exports at very low prices during the world recessive economic cycle lasting from 1990 to 1993; (ii) the increasing role played by socialist countries in international trade; (iii) the almost uninterrupted reduction (from 1988 to the end of 1993) of the real exchange rate, when domestic competitiveness dropped and import incentives rose. 
focuses on the main countries affected by antidumping or countervailing duties. Until 2003, duties were still imposed on products from 10 countries. The country upon which the highest number of duties has been imposed is China (34.2 \% of total duties), followed by the United States (28\%), South Korea (8.1\%) and Russia (6.3\%).

Table 5 - Initiated Investigations, Antidumping and Countervailing Duties by Country, 1987-2002

\begin{tabular}{||l|l|c|c|c|c||}
\hline$\#$ & Country & $\begin{array}{c}\text { Number of } \\
\text { investigations }\end{array}$ & $\begin{array}{c}\text { Percentage of } \\
\text { total } \\
\text { investigations }\end{array}$ & $\begin{array}{c}\text { Number of } \\
\text { duties in } \\
\text { effect in 2002 }\end{array}$ & $\begin{array}{c}\text { Percentage of duties } \\
\text { vis-à-vis the number } \\
\text { of investigations }\end{array}$ \\
\hline 1 & United States & 68 & $27.09 \%$ & 13 & $19.12 \%$ \\
\hline 2 & China & 46 & $18.33 \%$ & 36 & $78.26 \%$ \\
\hline 3 & Brazil & 25 & $9.96 \%$ & 4 & $16.00 \%$ \\
\hline 5 & Venezuela & 10 & $3.98 \%$ & 1 & $10.00 \%$ \\
\hline 6 & Gouth Korea & 9 & $3.59 \%$ & 2 & $22.22 \%$ \\
\hline 7 & Russia & 7 & $2.79 \%$ & & \\
\hline 8 & Spain & 6 & $2.39 \%$ & 5 & $83.33 \%$ \\
\hline 9 & Taiwan & 7 & $2.79 \%$ & & \\
\hline 10 & Ukraine & 6 & $2.39 \%$ & 2 & $33.33 \%$ \\
\hline 11 & Canada & 6 & $2.39 \%$ & 3 & $50.00 \%$ \\
\hline 12 & European Union & 4 & $1.99 \%$ & & \\
\hline 13 & Colombia & 4 & $1.59 \%$ & 2 & $50.00 \%$ \\
\hline 14 & Japan & 3 & $1.59 \%$ & 1 & $25.00 \%$ \\
\hline 15 & Indonesia & 2 & $1.20 \%$ & 1 & $33.33 \%$ \\
\hline & Other countries & 43 & $0.80 \%$ & 1 & $50.00 \%$ \\
\hline & Total & 251 & $18.40 \%$ & 8 & $18.60 \%$ \\
\hline \hline
\end{tabular}

Source: Based on data from UPCI’s Informe de Labores, 2002.

It is interesting to compare the number of duties in effect to the investigations concluded for each country. Despite the fact that the greatest number of investigations was initiated against products of US origin, only 19\% of concluded cases involving the United States have duties in force. By contrast, the percentage of duties in force vis-à-vis the investigations concluded in relation to China and Russia is $78 \%$ and $83 \%$, respectively (see Table 5 above). This asymmetry also stems from the different standards applied by the UPCI to market-oriented and nonmarket economies. 
If analyzed from the sectoral point of view, investigations follow clear-cut international patterns. First come steel products; second, chemicals, and third, textiles and clothing (Figure 4).

Figure 4 - Investigations Broken Down by Sector, 1987-2002

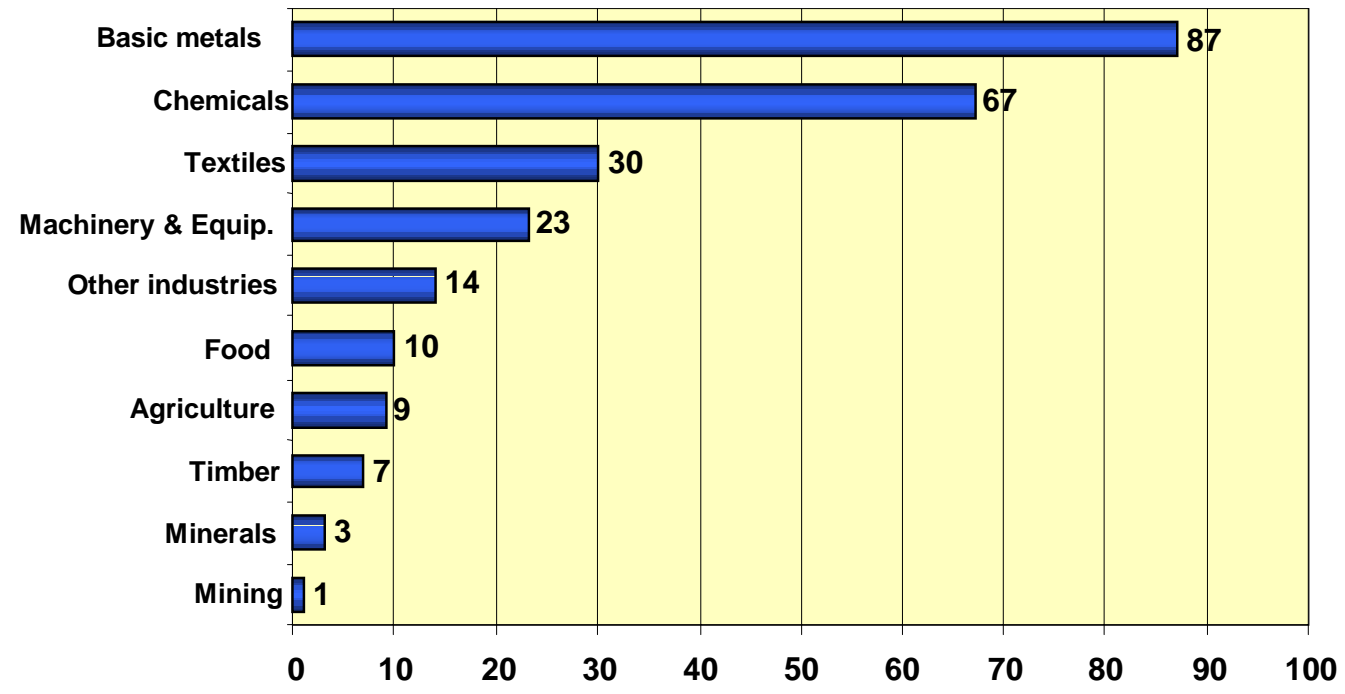

Source: Based on data from UPCI’s Informe de Labores, 2002.

Table 6 - Investigations and Duties by Type of Imported Good

\begin{tabular}{||l|c|c|c|c||}
\hline \hline & $\begin{array}{c}\text { Number of } \\
\text { investigations }\end{array}$ & $\begin{array}{c}\text { Percentage of } \\
\text { total number of } \\
\text { investigations }\end{array}$ & $\begin{array}{c}\text { Number of } \\
\text { duties in } \\
\text { force }\end{array}$ & $\begin{array}{c}\text { Percentage of duties } \\
\text { in force vis-à-vis the } \\
\text { total number of } \\
\text { investigations }\end{array}$ \\
\hline Consumer goods & 56 & $22.31 \%$ & 14 & $25.00 \%$ \\
\hline Intermediate goods & 187 & $74.50 \%$ & 63 & $33.69 \%$ \\
\hline Capital goods & 8 & $3.19 \%$ & 2 & $25.00 \%$ \\
\hline Total & 251 & $100.00 \%$ & 79 & $31.47 \%$ \\
\hline
\end{tabular}

Source: UPCI’s Informe Anual de Labores, 2002, and DOF’s Resolutions, 2003.

Table 6 shows how investigations are distributed per type of good. Intermediate products recorded the highest number of investigations (74\%), followed by consumer goods (22\%) and capital goods (8\%). With regard to the number of duties in force, intermediate goods rank first as well. 
This sectoral breakdown of investigations has changed over time. Between 1987 and 1992, $95 \%$ of all investigations concerned industrial supplies. ${ }^{52}$ Hence the need to conduct antidumping investigations with the greatest possible objectivity, since duties could affect the competitiveness of other domestic industries using such products.

This concern led the UPCI to create new administrative mechanisms to mitigate the effect of antidumping duties on some industries or prevent too great an impact on the consumer. This particular issue is discussed in Section IV.

\section{Safeguard Cases: Almost Non-Existent?}

To date, the UPCI has only conducted three safeguard investigations and has applied (bilateral) safeguard measures in only one occasion. Analysts have been suspicious for quite a long time of this absence of safeguard investigations in Mexico, assuming that in some cases the Mexican government was resorting to antidumping measures when safeguards should have been applied.

Mexican authorities systematically dismissed all safeguard requests filed before them on the grounds that such measures might introduce distortions in the manufacturing sector and, most especially, because of the compensations Mexico would have to pay its trade partners.

The UPCI's Informe de Labores 1991-1996 indicated that several safeguard consultations were requested, but there were only three cases where an investigation was formally requested: pork products, shoes and fish flour. The report stated that many of the safeguard cases filed "were settled by resorting to other types of measures." 53

In 1993, the National Commission of Hog Farming (CNP, in Spanish) filed the first formal request for safeguard measures, but it was dismissed on the grounds that it did not provide sufficient evidence. In 1994, the National Chamber of the Shoe Industry, and the Chambers of the Shoe Industries in the states of Guanajuato and Jalisco filed the second formal request for safeguard measures against imports of all types of shoes — with the exclusion of parts not

\footnotetext{
Reyes de la Torre (1995), p. 389.

SECOFI (1997), Informe de labores de la UPCI, 1991-1996, p. 93.
} 
manufactured in Mexico - from all countries, except the United States and Canada. The request was also dismissed for non-compliance with the main substantive provisions laid down in the Foreign Trade Act.

The first safeguard investigation in Mexico was initiated in November 1993. It involved a bilateral safeguard against fish flour imports pursuant to the Mexico-Chile Free Trade Agreement. The investigation was initiated ex officio one month after the conclusion of an antidumping investigation against the same product, as a result of which no antidumping duties were imposed despite the existence of evidence of dumping margins and serious injury to the domestic industry. However, no causal link was proved.

The decision to initiate ex officio safeguard proceedings was strongly influenced by the prevailing political circumstances; it was almost a given that the Mexican authority would take safeguard actions. In fact, a process of consultation with Chilean authorities had already started and a preliminary agreement had even been reached as to the characteristics of the action and the amount of the compensation. This decision was radically changed when the 1994 crisis broke out — the peso was devalued by 50\% vis-à-vis the US dollar, and the ensuing change in market conditions made all imports shrink substantially because of the high increase in their relative prices. Thus, safeguard measures were no longer necessary.

It was not until 2002 that the UPCI accepted and initiated the second and third safeguard claims. The first one was a request for taking global measures against timber products and the second one involved bilateral measures against imports of US chicken legs and thigh meat. This case was conducted in conformity with NAFTA Chapter VIII and concluded with a tariff increase and a duty-free quota for the border region. The measures taken as well as the compensation were accepted by the chicken industries in both countries almost before the investigation was initiated; it was the private sectors that pushed their respective governments to carry out this proceeding. In the timber case, no final determination has been issued as of August 2004. 


\section{Lessons: Case Studies}

Having analyzed the history of the antidumping system focusing on its cases, institutions and legal framework, this section will now present cases illustrating broader and major relevant or distinctive aspects of the contingent trade defense system in Mexico. As of 2003, 262 new country-product investigations - excluding, inter alia, review proceedings, product coverage, five-year reviews - were initiated. Among them, there is a wide scope of cases from which we can draw interesting lessons for many sectors and countries.

\section{The China Package and Multi-Country/Multi-Product Steel Cases}

The cases identified as China Package and Multi-Country/Multi-Product Steel serve the purpose of illustrating the history of contingent protection mechanisms in Mexico. These cases are indissolubly linked to the deepening of the Mexican trade liberalization process and constitute clear evidence of the role played by such mechanisms in supporting economic opening processes in countries like Mexico.

Between 1992 and 1993, the government of Mexico was strongly pressured by sectors adversely affected by the opening of the economy, mainly the Mexican steel manufacturers and other manufacturing sectors — shoe, textile, clothing and toy industries, among othersthus jeopardizing the credibility of the newly created institutions concerned with trade defense mechanisms.

On the one hand, the steel industry filed a series of requests for antidumping investigations against almost all basic steel products and international supply sources. Such antidumping duties, if applied, would have an extremely negative effect on the main local manufacturing industries and on the competitiveness of Mexican exporters, thus reverting many of the benefits accomplished so far with the liberalization process.

The Mexican authority delayed the decision-making process to initiate investigations and, later on, to issue provisional or final determinations in the steel cases, the requests of which were filed in the first half of 1993. However, it had to take immediate contingent measures in other manufacturing sectors involving final products which were also exerting firm pressure on the government, based on what they regarded as an extreme liberalization policy and on the 
inefficiency of the new trade defense instruments. Both aspects - crucial for a new modernizing process - were beginning to be strongly and dangerously questioned all over the country.

One of the ways in which the Mexican government responded was by filing an ex officio antidumping investigation package against products of Chinese origin, for which high antidumping duties were applied; since the initiation of the investigation was published in conformity with the Law Regulating Article 131, i.e. two months before the publication of the new Foreign Trade Act. Provisional duties were applied to around 3,000 tariff items.

Table 7 - The “China Package” and Other Cases against Chinese Products during 1993

\begin{tabular}{|c|c|c|c|c|c|c|}
\hline \# & Product & Country & $\begin{array}{c}\text { Date of } \\
\text { initiation }\end{array}$ & \begin{tabular}{|c|} 
Date of final \\
determination
\end{tabular} & $\begin{array}{c}\text { Duty applied upon } \\
\text { initiation }\end{array}$ & Final duty applied \\
\hline 1 & Toys* & China & 14-Apr-93 & 25-Nov-94 & \begin{tabular}{|l|}
$351 \%$ \\
\end{tabular} & $351 \%$ \\
\hline 2 & Shoes* & China & 15-Apr-93 & 30-Dec-03 & $1,105 \%$ & $1,105 \%$ \\
\hline 3 & Tools* & China & 15-Apr-93 & 11-Nov-94 & $312 \%$ & $312 \%$ \\
\hline 4 & Clothing* & China & 15-Apr-93 & 18-Oct-94 & $533 \%$ & $533 \%$ \\
\hline 5 & Chemicals* & China & 15-Apr-93 & 18-Oct-94 & $673 \%$ & $209 \%$ \\
\hline 6 & Textiles* & China & 15-Apr-93 & 18-Oct-94 & $501 \%$ & $501 \%$ \\
\hline 7 & $\begin{array}{l}\text { Electrical machines and } \\
\text { equipment* }\end{array}$ & China & 15-Apr-93 & 18-Nov-94 & $129 \%$ & $129 \%$ \\
\hline 8 & Bicycles & China & 15-Apr-93 & 22-Sep-94 & $594 \%$ & $279 \%$ \\
\hline 9 & Pencils & China & 09-Aug-93 & 18-Oct-94 & $451 \%$ & $451 \%$ \\
\hline 10 & Valves & China & 01-Nov-93 & 18-Oct-94 & 0 & $105 \%$ \\
\hline 11 & Pencil sharpeners & China & 19-Nov-93 & 18-Oct-94 & 0 & $145 \%$ \\
\hline 12 & Baggage and bags & China & 29-Nov-93 & 25-Nov-94 & 0 & 0 \\
\hline
\end{tabular}

* Cases corresponding to the China Package.

Source: Based on data from World Trade Atlas and several DOF.

The decision to initiate investigations and impose high antidumping duties against Chinese products was important from the political perspective. However, its impact from the commercial point of view had been carefully considered. Mexico did not breach any international trade agreement, since these investigations involved products from a non-WTO Member. Additionally, most antidumping duties were applied to consumer goods, thus avoiding any impact on Mexican exports’ competitiveness.

Table 8 below illustrates — through the multi-country/multi-product steel cases filed in the same year the China Package was published - some aspects of the ambivalent and apparently 
contradictory behavior of the federal government with regard to the contingent trade protection system. Unlike claims against China, here no duties were imposed upon initiation of the investigation, some countries were excluded from duty coverage, most investigations did not conclude until December 1995 —in fact, these cases, collectively, were the lengthiest in the history of antidumping proceedings in Mexico. In addition, with the purpose of mitigating the negative effect that antidumping duties might have upon some steel-using industries, the end-use certificate was created. This instrument would allow importing some products on duty-free conditions provided that importers could prove that those products were intended for certain end uses.

Table 8 - Multi-Country/Multi-Product Steel Package, 1992-1993

\begin{tabular}{|c|c|c|c|c|c|c|}
\hline \# & Product & Country & $\begin{array}{c}\text { Date of } \\
\text { initiation }\end{array}$ & $\begin{array}{c}\text { Date of final } \\
\text { determination }\end{array}$ & $\begin{array}{l}\text { Antidumping } \\
\text { duty upon } \\
\text { initiation }\end{array}$ & $\begin{array}{c}\text { Final } \\
\text { antidumping } \\
\text { duty }\end{array}$ \\
\hline 1 & Lined flat steel & U.S.A. & 30-Jun-93 & 11-Nov-94 & None & None \\
\hline 2 & Hot rolled sheet & Germany & 27-Oct-93 & 30-Dec-95 & None & None \\
\hline 3 & Hot rolled sheet & Brazil & 27-Oct-93 & 30-Dec-95 & None & $31.41 \%$ \\
\hline 4 & Hot rolled sheet & Canada & 27-Oct-93 & 30-Dec-95 & None & $45.86 \%$ \\
\hline 5 & Hot rolled sheet & South Korea & 27-Oct-93 & 30-Dec-95 & None & None \\
\hline 6 & Hot rolled sheet & The Netherlands & 27-Oct-93 & 30-Dec-95 & None & $56.54 \%$ \\
\hline 7 & Hot rolled sheet & Venezuela & 27-Oct-93 & 30-Dec-95 & None & $80.95 \%$ \\
\hline 8 & Cold rolled sheet & Germany & 28-Oct-93 & 27-Dec-95 & None & $185.76 \%$ \\
\hline 9 & Cold rolled sheet & Australia & 28-Oct-93 & 27-Dec-95 & None & None \\
\hline 10 & Cold rolled sheet & Canada & 28-Oct-93 & 27-Dec-95 & None & None \\
\hline 11 & Cold rolled sheet & South Korea & 28-Oct-93 & 27-Dec-95 & None & None \\
\hline 12 & Cold rolled sheet & Brazil & 28-Oct-93 & 27-Dec-95 & None & $31.57 \%$ \\
\hline 13 & Cold rolled sheet & U.S.A. & 28-Oct-93 & 27-Dec-95 & None & None \\
\hline 14 & Cold rolled sheet & Venezuela & 28-Oct-93 & 27-Dec-95 & None & $55.75 \%$ \\
\hline 15 & Steel plate & Brazil & 27-Oct-93 & 29-Dec-95 & None & $37.32 \%$ \\
\hline 16 & Steel plate & Canada & 27-Oct-93 & 29-Dec-95 & None & None \\
\hline 17 & Steel plate & U.S.A. & 27-Oct-93 & 29-Dec-95 & None & None \\
\hline 18 & Rolled steel plate & Brazil & 28-Oct-93 & 28-Dec-95 & None & $23.95 \%$ \\
\hline 19 & Rolled steel plate & Canada & 28-Oct-93 & 28-Dec-95 & None & $31.08 \%$ \\
\hline 20 & Rolled steel plate & Korea & 28-Oct-93 & 28-Dec-95 & None & None \\
\hline 21 & Rolled steel plate & U.S.A. & 28-Oct-93 & 28-Dec-95 & None & None \\
\hline 22 & Rolled steel plate & South Africa & 28-Oct-93 & 28-Dec-95 & None & None \\
\hline 23 & Rolled steel plate & Venezuela & 28-Oct-93 & 28-Dec-95 & None & $84.05 \%$ \\
\hline 24 & Corrugated rod & Brazil & 29-Nov-93 & 11-Aug-95 & None & $57.69 \%$ \\
\hline 25 & Corrugated rod & Spain & 29-Oct-93 & 10-Oct-94 & None & None \\
\hline
\end{tabular}

Source: Based on data from the 2002 Countervailing Duty Agreement, UPCI's Annual Report 2002, Resolutions published in the DOF. 
It should be noted that in 1993, as another federal government's response to the pressure from several sectors upon the new trade defense system, the Advisory Council on International Trade Practices (Consejo Consultivo de Prácticas Comerciales Internacionales or CCPCI) was created as an advisory and technical opinion body for the private sector, made up of representatives from the leading sectors using the new contingent protection instruments. Thus, the Commerce Secretary pushed the unsatisfied business sector to meet once a month with representatives from the Secretariat and the UPCI's management to discuss the technical and methodological issues regarding the application of antidumping instruments and to listen to alternative solutions to such issues.

Participation in this forum would be on a personal representation basis and would summon experts in the field or representatives of companies having filed investigations with the UPCI. It was agreed that lobbies would be forbidden. Thus, the federal government managed to channel dissatisfaction and found a mechanism to raise awareness among business representatives and authorities on the problems faced by both in relation to these proceedings. $^{54}$

\section{Mechanisms to Mitigate the Negative Effects of Antidumping Duties}

This section analyses different kinds of mechanisms applied by the UPCI to soften the impact of antidumping duties applied between 1991-1996, a distinctive feature of the UPCI's administration practice during that period.

\section{A. Lesser Duty Rule (LDR)}

Several provisions included in the applicable laws empowered the investigating authority to impose antidumping or countervailing duties for an amount less than the margins found, provided that they were sufficient to eliminate the injury or threat of injury caused by the imports involved.

The CCPCI's creation was formalized later on, in August 1994, when the DOF published the Agreement whereby the Advisory Council on International Trade Practices (Consejo Consultivo de Prácticas Comerciales Internacionales) was created and its functions established. 
In 1991, the UPCI tried to develop a methodology that would draw a clearer line between the effect of dumping and the effect of other factors on the industry so as to be able to apply antidumping duties for less than the margin of dumping found. The European Community applied lesser duties in its investigations on a regular basis, but its methodology did not suit the UPCI's authorities because its extrapolation to Mexico at that time would have been protectionist in some Mexican sectors that still faced high tariffs, since it was based on the price of domestic manufacturers. That is why the UPCI developed a methodology of its own, which was first applied in 1991 in the Di-iodohydroxy-quinoline case.

Table 9 - Cases in which the Lesser Duty Rule was Applied, 1991-1996

\begin{tabular}{|c|c|c|c|c||}
\hline $\begin{array}{c}\text { Date of the final } \\
\text { determination }\end{array}$ & Product & Country & $\begin{array}{c}\text { Final dumping } \\
\text { margin }\end{array}$ & $\begin{array}{c}\text { Lesser Duty } \\
\text { (less than the } \\
\text { margin found) }\end{array}$ \\
\hline 17-Oct-91 & Di-iodohydroxy-quinoline & India & $\begin{array}{c}15.56 \\
\text { USD/kg*/ }\end{array}$ & 4.09 USD/kg \\
\hline 27-Nov-92 & Telephone connectors & United States & 35.34 USD/kg & 4.59 USD/kg \\
\hline 8-Dec-92 & Tri-poly-phosphate & Spain & $50 \%$ & $36 \%$ \\
\hline 23-Dec-93 & Hydrogen peroxide & United States & $72 \%$ & $34.5 \%$ \\
\hline 27-May-96 & Sulfuric acid & Japan & $2,484 \%$ & $91.10 \% * * /$ \\
\hline \hline
\end{tabular}

*/ In the provisional determination, a $12.34 \mathrm{USD} / \mathrm{kg}$ (equal to the dumping margin) was applied.

$* * /$ In the provisional determination, a lesser duty than the margin of $166.67 \%$ was applied.

Source: Based on data taken from determinations published in the DOF.

\section{(a) The Di-Iodohydroxy-Quinoline Case}

The Di-Iodohydroxy-Quinoline case features three interesting aspects: (i) it was the first case in which the Mexican authority applied a lesser duty than the dumping margin; (ii) its determination explicitly revealed the new authorities' concerns about and conception of the administration of contingent trade protection mechanisms in a context in which the Mexican trade liberalization process was being consolidated and reinforced; and (iii) it meant the use, for the first time, of a method different from any other employed until 1991 by the few antidumping systems in force that applied lesser duties in the world. 
In its final determination, the authority stated that, according to its view:

...the dumping margin is excessive to be taken as a reference, since it would encourage the prohibition of importing goods under investigation, market concentration and monopoly practices, to the detriment of free competition. (Emphasis added.) ${ }^{55}$

The decision to lower the final antidumping duty was adopted by the competent authority even though no request was filed either by the appearing importers or by the exporters of the product, who did not appear during the proceedings. Such a decision was also independent of the findings in the injury determination proceeding, during which a substantial injury to the industry was proved. ${ }^{56}$

Instead, the decision to apply the LDR resulted from having analyzed the structure of the international market for the product in question as well as the potential market concentration and market power that the domestic manufacturer would gain, according to the competent authority, if a duty amount equal to the calculated margin were applied. According to the information analyzed, the Di-Iodohydroxy-Quinoline was an active ingredient in a medicine for amoebas manufactured in only three countries in the world: Mexico, India and Germany. Besides, the Mexican company filing the request was commercially linked with the German manufacturers and exporters. If provisional antidumping duties were applied to the Indian product, such imports from India would drop to zero and the only alternative source of supply would be the German company associated with the domestic company that had submitted the request for investigation. This would confer the Mexican company too strong a power over the market and, consequently, over prices, as feared by the authority.

Taking these elements into account, the authority analyzed the domestic price of the investigated product prior to the significant market penetration of Indian imports and found out that the price was equivalent to that of the product of German origin. The Mexican authority reached the conclusion that the price differential between the Mexican and the Indian product could be corrected by applying a lesser duty of $4.09 \mathrm{USD} / \mathrm{kg}$ rather than the margin of

\footnotetext{
55 Finding \# II of the final determination on the import of di-iodohydroxy-quinoline, product of Indian origin included in tariff item 2933.40.01 of the General Import Duty Law, published in the DOF on October $17^{\text {th }}$, 1991 (Final determination on di-iodine).

$56 \quad$ Final determination on di-iodine.
} 
15.56 USD/kg. In this way, the injury to the industry would be eliminated, while the Mexican and German business association would be prevented from increasing its prices above fair or market competitive prices. ${ }^{57}$

This case gave rise to a novel methodology ${ }^{58}$ that would enable Mexican authorities to apply antidumping duties that were less than dumping margins, and to additionally determine the existence of a causal link, a key aspect to drawing a distinction between the protectionist and non-protectionist use of antidumping instruments.

(b) The Connectors, Tri-poly-phosphate, and Hydrogen Peroxide Cases

In the three cases filed after that of Di-Iodine in which LDR was applied, the method used was that of the unitary approach to international prices, developed after the Di-Iodine case. The key goal of this approach was to find a relevant fair or undistorted price in the Mexican market, on the basis of which to determine a price as a sort of "injury margin" and to adjust the antidumping duty accordingly. A peculiar aspect of the connector, tri-poly-phosphate and hydrogen peroxide cases was the important market share of the domestic industry, amounting to $100 \%, 77 \%$ and $100 \%$, respectively.

In the case of the telephone connectors, ${ }^{59}$ the Mexican antidumping authority concluded that the prices resulting from imposing a duty amount equal to the dumping margin "would exceed the highest historical levels ever recorded and would even exceed those observed in monopoly situations.” ${ }^{\circ 0}$ It determined, therefore, that the final antidumping duty amount would be less than the dumping margin, since the new rate was sufficient "to eliminate the injury caused as a direct result of unfair practices.” 61

“...the Secretariat considers that the final countervailing duty of USD 4.09 is enough to discourage the import of goods flowing into the national territory on unfair trade conditions and to eliminate the injury to the domestic industry, thus ensuring free competitive prices” Finding \# IV of the final determination on di-iodine. Unitary approach to international prices.

Final determination on imported connectors for telephone cables; goods under tariff item 8536.90.23 of the General Import Duty Law from the USA, DOF, November $27^{\text {th }} 1992$ (Final determination on connectors or determination on telephone connectors).

Monopoly prices were defined as those existing when the requesting company was the only supplier in the domestic market, paragraph 44 of the final determination on connectors. We assume the authority was making reference to the time in which the market was not open to imports.

Paragraph 44, Final determination on connectors. 
In the investigation on connectors, the price evolution of the requesting company was examined and it was observed that the Mexican product had experienced a drop in its domestic prices before competing with dumped prices. Consequently the authority concluded that "such price reduction cannot be attributed to dumping practices." ${ }^{2}$ The remaining part of the price squeeze was attributed to the importers' dumping prices; therefore, a duty was applied on the basis of that part of the price reduction.

In the case of the tri-poly-phosphate, the Mexican authority explained that it had used an international reference price to determine the lesser duty. Specifically, it stated that "all the injury caused to the domestic industry cannot be attributed to the full dumping margin, since the ceiling price that the domestic industry could feasibly expect would be that of the US product placed in the Mexican market.”63

In the case of the hydrogen peroxide, the authority also applied the unitary approach to international prices. It considered that a duty equal to the dumping margin found "would result in the overprotection of the domestic industry by taking import prices to higher levels than necessary to avoid a drop in domestic prices."64 Thus, the non-distorted international price adopted as reference for the antidumping duty was the average price of the US imports that the requesting company had brought into the country under fair conditions, according to its statement. $^{65}$

\section{(c) The Sulfuric Acid Case and the "Public Interest" Clause}

Several years went by before the Mexican authority applied the lesser duty rule again. The pressure exerted by the domestic industry upon the new authorities limited the application of the new approach for injury determination purposes. Once dumping was proven to exist, the domestic industry could not find any justification for the Mexican authorities to avoid imposing duties or to lower those duties if the industry showed negative indicators. It was not until 1996 when a lesser duty was applied again.

\footnotetext{
$62 \quad$ Paragraph 50, ibid.

63 Paragraph 49, Final determination on sodium tri-poly-phosphate imports, DOF, June $28^{\text {th }} 1993$.

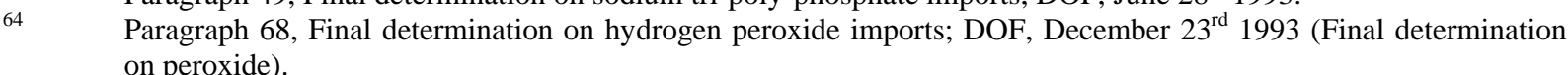
Paragraph 69, ibid.
} 
In the case of the sulfuric acid, the UPCI applied the LDR making reference to the "public interest clause,” the name under which Article 88 of the Foreign Trade Act came to be known. This article indicated that "when imposing a countervailing duty [...] the Secretariat shall ensure as far as possible that such measure, in addition to providing timely defense for the domestic industry, avoids any negative impact on other production processes or on consumers.” In this case, the decision was founded on the idea that the fertilizer manufacturing industry — the main user of sulfuric acid — should not be affected more than necessary. ${ }^{66}$

The dumping margin determined during the proceeding was 2,483\% for Japanese sulfuric acid. The lesser duty was imposed on the basis of the indifference price of producing sulfuric acid by burning sulfur. For the requesting company, sulfuric acid was an accessory product; it was a byproduct manufactured involuntarily from the gas emissions of its copper smelters and as a result of environmental regulations that imposed the obligation to process emissions to avoid air pollution.

Given the afore-mentioned explanation, it was usually observed that as the world's copper production increased, so did the production of sulfuric acid, thus lowering its price. At that stage, the fertilizer industry stopped burning sulfur to produce sulfuric acid and resumed its production as soon as the price of the sulfuric acid rose again. In this context, the Mexican authority decided that "even in the absence of imports, the sulfuric acid price in the domestic market is determined by the reference price of the main domestic consumers, "67 who are the fertilizer manufacturers. Thus, the authority estimated the indifference price of sulfuric acid on the basis of how much it cost to produce the acid in Mexico by burning sulfur.

\section{(d) Changes in the Application of the Lesser Duty Rule}

Between 1993 and 2001, lesser duties were applied only on one occasion. Since 2002 this mechanism has been applied in Mexico with renewed intensity and under a different approach. Unlike the 1991-1993 period, when an attempt was made to use the unitary approach to international prices systematically; in recent cases the application of lesser duties is based on what is known as market "non-injury price”. To estimate the final duty amount, import prices

66 Paragraph 132, Final determination of the antidumping investigation on sulfuric acid imports, DOF, May $25^{\text {th }} 1996$. Paragraph 133, ibid. 
plus the dumping margin found are compared against non-injury prices, which are usually the domestic prices during a period prior to the one being investigated.

The new Mexican rule is closer to the one used by the European Commission (EC), but lacks a strong methodological foundation and differs from the approach used in Mexico in the early 90s. The Mexican and European rules are similar in the sense that both are based on an endogenous reference to their domestic production, while ignoring current international prices or the prices relevant to fair competition.

Table 10 shows the cases in which a duty less than the margin has been recently applied.

Table 10 - Cases in which a Duty Below the Dumping Margin was Applied, 2001-2004

\begin{tabular}{||c|c|c|c|c||}
\hline $\begin{array}{c}\text { Date of final } \\
\text { determination }\end{array}$ & Product & Country & $\begin{array}{c}\text { Final dumping } \\
\text { margin }\end{array}$ & Lesser Duty \\
\hline 22-Jun-01 & Polyester filament fabrics & Korea & $31.61 \%$ & $16.03 \%$ \\
\cline { 3 - 5 } & & Taiwan & $11.69 \%$ & $11.00 \%$ \\
\hline 2-Oct-02 & Steel beams & Brazil & $80.00 \% *$ & $42.49 \%$ \\
\hline 13-Jan-03 & Standard tubing & Guatemala & $29.93 \% * *$ & $25.87 \%$ \\
\hline 10-Jun-03 & Monobutyl ether & United States & $54.25 \%$ & $32.56 \%$ \\
\hline 17-Jul-03 & Steel chains & China & 0.80 USD/kg & 0.72 USD/kg \\
\hline 24-Sep-03 & Ferro-silico-manganese & Ukraine & $95.74 \%$ & $51.28 \%$ \\
\hline 21-Apr-04 & Seamless steel pipes & Russia & $111.37 \%$ & $79.65 \%$ \\
\cline { 3 - 5 } & & Romania & $42.00 \%$ & $42.00 \%$ \\
\hline 13-May-04 & Tubular goods & Venezuela & $54.69 \% * * *$ & 49.94 \\
\hline 3-Aug-04 & $\begin{array}{c}\text { Sodium } \\
\text { hexametaphosphate }\end{array}$ & China & $124.96 \%$ & $102.22 \%$ \\
\hline 4-Aug-04 & Steel connections & China & $111.41 \%$ & $81.04 \%$ \\
\hline
\end{tabular}

Source: Based on data from relevant determinations published in the DOF.

The diverse ways in which LDR has been applied result from the different criteria held by officials engaged in administering antidumping instruments. This situation also reveals the broad discretionality prevailing in the administration of the antidumping system, despite all past attempts in the opposite direction. 


\section{B. End-Use Certificates}

End-use certificates were the result of deep controversy between the parties which led to a dispute because of the differences in the technical specifications of the product under investigation, the several uses of the product depending on the industry involved, and the domestic industry's capacity to supply each specific type of product. ${ }^{68}$

In some cases related to steel, imported goods were usually replaceable by other domestically manufactured products, but that was not possible in the case of some specific end uses. Therefore, the Mexican authority sought to prevent these inputs — so essential for important manufacturing and exporting sectors in Mexico, such as the automotive, household appliances, capital goods, and engineering industries - from becoming unjustifiably expensive. The case of the cold-rolled sheet illustrates the rationale for these end-use certificates and how they were applied. ${ }^{69}$

The clearest example showing the origin of this measure was that of the cold-rolled sheet thicker than 52 inches. According to exporters' allegations, domestic manufacturers were incapable of manufacturing cold-rolled sheet thicker than 52 inches - a fact that was entirely taken for granted by the requesting parties, since local production facilities had technical limitations to manufacture the product in this thickness range, though it was not so with regard to all other specifications of the product. Domestic manufacturers, in turn, insisted on the fact that there was practically no demand from the market to produce cold-rolled sheet of such thickness and that imported sheets of such dimensions were acquired by distribution and service centers simply to be cut and sold in the sizes that were manufactured at the domestic level. Thus, manufacturers asked the authority not to exclude the sheet thicker than 52 inches from the antidumping duty. ${ }^{70}$

Some users, such as the car and tubing industries, proved that sheets thicker than 52 inches were required for several production processes. The investigating authority also admitted that,

$68 \quad$ Paragraph 7, ibid.

69 This case is based on information from the final determinations in antidumping and anti-subsidy investigations involving cold-rolled sheet imports, merchandise under tariff items 7209.12.01, 7209.13.01, 7209.22.01 and 7209.23.01 of the General Import Duty Law, from Canada, United States of America, Australia, the Republic of Korea, Venezuela, the Federal Republic of Germany and Brazil. Determination published in the DOF, December 27th 1995 (Final determination on cold-rolled sheet). 
by making a longitudinal cut, sheets thicker than those locally manufactured could be turned into narrower sheets, such as those manufactured by the domestic industry in the period under investigation. Therefore, the authority concluded that in order to declare the non-existence of a like domestic product —a sheet thicker than 52 inches — it would be necessary to specify an end use not allowing thinner substitutes. ${ }^{71}$

The same conclusion was drawn for sheets having different carbon content. In this case, it was determined that for some end uses, particularly demanding cutting processes, differences in carbon content were not relevant to ensure the malleability required by the sheet to resist such processes.

Consequently, the authority excluded some types of steel sheets from the application of antidumping duties established according to their end use. This determination imposed the need to have a mechanism in place that would enable the authority to exempt such products from the corresponding antidumping duty. Thus, the end-use certificate was created. This certificate was a free-format instrument that had to comply with certain features. In addition, a monitoring procedure was created. ${ }^{72}$

\section{Statements of Exclusiveness}

The statement of exclusiveness, the third mechanism to mitigate the effects of antidumping duties, was created at the time Chinese toys were investigated. Its purpose was to exempt from antidumping duties imported toys that, albeit similar to those manufactured in Mexico, could not cause any injury to the domestic industry because of their price and some distinct characteristics that turned them into unique products. This market situation is typically exemplified by Barbie dolls.

The Mexican authority drafted a definition specific to its final determination, whereby exclusive products were to be understood as:

\footnotetext{
Paragraph 506, ibid.

Paragraphs 507 y 510, ibid.

Sub-paragraph A, paragraph 674, ibid.
} 
...toys from China imported under tariff items subject to countervailing duties which [...] do not cause any injury to the domestic industry for two main reasons: (1) because they have been so clearly differentiated by their designer that there cannot possibly be an identical local product, being additionally protected by copyright or patents of characters, mechanisms, designs or any other specific feature, that make them exclusive vis-à-vis the toys manufactured in the Mexican market, and (2) because, given their highly differentiated character, they are sold at high prices in the Mexican market, for which reason the price of these products cannot possibly be the cause of any negative impact on the production or price of other locally manufactured toys that may have similarities with these exclusive products imported from the Popular Republic of China. $^{73}$

As was the case with end-use certificates, the statement of exclusiveness was a free-format instrument in which the importer had to state the net unit price of the exclusive product, the name of the copyright holder or owner of the patent of characters, mechanisms, designs or any other distinct feature, among other data. A monitoring system was also devised.

Another interesting aspect worth mentioning of this determination concerning toys was that the investigating authority committed itself to review how effectively this mechanism worked in a six-month period "and at any time, when so justified." ${ }^{, 74}$ In the document, no explanation was given as to why it was deemed necessary to review this mechanism in such a short time, but the reason for this decision lay with the fact that in the Foreign Trade Commission the representatives of the Federal Commission of Economic Competition conditioned their favorable vote to a review to be carried out after six months of its implementation, based on their fears that this mechanism might confer strong market power to some economic agents.

However, the review was not conducted in six months' time as prescribed; it was not until 1998, when relevant modifications introduced to the statement of exclusiveness mechanism were published that the review was made. ${ }^{75}$ The review's objective, though, was far removed

Sub-paragraph $\mathrm{H}$, paragraph 196, Final determination in the antidumping investigation involving toy imports, merchandise under tariff items of headings 95.01, 95.02, 95.03, 95.04, 95.05, 95.06, 95.07 and 95.08 of the General Import Duty Law, from the Popular Republic of China regardless of their country of dispatch, DOF, November $25^{\text {th }}$ 1994 (Final determination concerning toys).

Ibid.

Resolution modifying the mechanism for the statement of exclusiveness provided for in the Final determination in the antidumping case involving imported toys, merchandise under tariff items of headings 9501, 9502, 9503, 9504, 
from the spirit that originally inspired the idea in 1994. The 1998 determination explicitly observed that the mechanism would be revised because of the breaches and abuses committed by importers with the statement of exclusiveness. Therefore, the investigating authority eliminated the free-format instrument and instead set a compulsory procedure involving import permits to introduce the so-called exclusive products without paying antidumping duties, a procedure under the control of the Secretariat of Economy, with the power to either grant or reject requests for permits.

\section{The Unitary Approach to International Prices and the Causal Link: The Bond Paper Case}

The unitary approach to international prices consists of establishing a causal link between the behavior and level of domestic prices, export prices under dumping conditions, and fair or undistorted international prices. ${ }^{76}$ Dumped export prices may affect domestic production prices, either lowering or anchoring them at a level that might not necessarily be equal to the dumping margin determined for exporters who have been investigated. If during the dumping practice period domestic production prices are lower than a undistorted international price relevant to an importing market, and if this is caused by competition with like or identical products at dumped prices, it can be concluded that there is a causal link between dumped prices and domestic production prices and, if applicable, vis-à-vis the prices in the productive sector involved.

On the contrary, if dumped prices of imported goods are the direct cause of a reduction in domestic prices, but the new price levels match undistorted international prices relevant to the importing country, then it may be inferred that there is no causal link between the amount of the dumping margin determined and the domestic price reduction.

9505, 9506, 9507 and 9508 of the General Import Duty Law, from the Popular Republic of China, regardless of the country of dispatch, published in the DOF on November $25^{\text {th }} 1994$. new methodological approach was during the International Seminar on Unfair Trade Practices, organized by the SECOFI and the Institute for Legal Research, Universidad Nacional de México, held at the Institute from October $27^{\text {th }}$ to $29^{\text {th }} 1993$. Reyes de la Torre, 1995. 
In line with this, the Mexican antidumping authority applied the lesser duty rule to the margin of dumping in the first cases, since this method enabled the authority to quantify the amount necessary to set the export price of the dumped product higher than the international price relevant to the domestic market.

Some basic rules can be identified in the application of this approach to estimate a duty amount less than the dumping margin that should be sufficient to correct the injury caused by dumped prices: (i) if the relevant international price is equal to the normal value, the duty should be equivalent to the dumping margin; (ii) if the relevant international price is between the normal value and the export price, the duty amount should be such that it may position the dumped export price higher than the international price, and (iii) if the relevant international price is equal to the dumped export price, then the dumping practice does not cause any injury; dumping exporters trade their products in the world market at the same prices as non-dumping exporters; as a consequence, domestic producers face fair competition prices, so that no antidumping duties need to be imposed.

The main limitation of this approach is its difficulty to identify the international price relevant to each case. ${ }^{77}$ In addition, it involves other equally important limitations. For example it might be difficult to obtain accurate information from domestic and international markets, to adopt a suitable method to determine the market power of the different actors, their pricefixing arrangements, and their influence on the market prices.

The first investigation on bond paper, initiated in Mexico in October 1993, constitutes a clear example of how the unitary approach to international prices is used to establish the causal link between the dumping margin amount and the injury to the domestic productive sector involved. ${ }^{78}$ The underlying principle of the unitary approach to international prices implies that, even if an antidumping duty equivalent to the dumping margin is determined for each

77 It is relatively easier to find an undistorted international reference price in raw materials or commodities, since in these cases arbitrage is relatively common and information is available in international stock markets. In the case of differentiated products, it is far more difficult to identify the international price relevant to a specific market, but alternatively one can adopt the average export price of the countries exporting representative volumes to the country conducting the investigation, provided those countries are not involved in the investigation or else all parties involved explicitly recognize such countries as having undistorted prices. 
investigated exporter, the domestic industry will not be able to increase its prices - the situation being the same as if no duties were applied.

In the final determination concerning bond paper imported from the United States, ${ }^{79}$ the authority explained that it had access to information furnished by US exporters accounting for 95\% of the export volume to Mexico during the period subject to investigation. Sixty-one percent of such exports were made by Georgia Pacific Corporation (GPC), an exporter whose dumping margin was $8 \%$ negative, i.e. its selling price in the Mexican market was higher than the normal value. ${ }^{80}$

Since there was a non-dumping exporter, representative of US bond paper exports to Mexico, the Mexican authority analyzed its selling prices in the Mexican market ${ }^{81}$ against comparable prices of other competitors as well as of domestic producers. As a result of this analysis, it was found that GPC's prices were the lowest in the Mexican market during the investigated period, which accounted for the increase in the demand by Mexican customers of this exporter's products.

In addition, the price level in the Mexican market of other dumping exporters was, on average, 2\% higher than GPC's. The conclusion was that dumping exporters behaved as price followers. Besides, fair prices, i.e. those of GPC, "were, on average, 15\% lower than the domestic prices of bond paper, for which reason the fair price was considerably lower than the domestic industry price in the investigated period; therefore, the fair price exerted a strong downward pressure on the domestic market, since it represented the largest share of the imported product in Mexico.,

Given the afore-mentioned factors, the investigating authority concluded that the dumped prices of some US exporters were not the direct reason for the deterioration of some indicators

Final determination in the antidumping investigation on imported bond paper, a merchandise under tariff items 4802.52.01 and 4802.52.99 of the General Import Duty Law, from the United States, regardless of the country of dispatch, DOF, November $18^{\text {th }} 1994$ (Final resolution on bond paper).

Ibid.

Paragraphs 189 to 193, ibid.

These prices refer to prices in Mexico; paragraph 190 of the determination on bond paper explains the procedure followed by the authority to estimate the price: all expenses, insurance, freight and tariffs incurred in by the Georgia Pacific Corporation to bring the product to the customer's plant in Mexico were added to the selling price of the company's bond paper in the Mexican market.. 
of the domestic industry; the lowest price in the domestic market during the period under investigation was neither a distorted nor an unfair price; it was this price that caused a widespread drop of domestic prices, which reached fair price levels; therefore, no antidumping duties $^{83}$ were imposed on exporters resorting to dumping practices.

The unitary approach to international prices may be both useful and interesting but, unless more analytically rigorous and formal rules are developed, it might lead to a dangerous and excessive oversimplification and trivialization of the complex relations operating in the markets.

\section{Final Considerations}

From the history of the creation and strengthening of mechanisms and institutions engaged in the administration of contingent trade protection measures in Mexico we can draw some conclusions that might be of interest to both public officials and academic analysts. The economic opening in Mexico took place in an extremely complicated macro-economic context. In the early 1980s, Mexico underwent a severe economic crisis as a result of the economic model applied in the country for 30 years. It was decided then that the only way for the country to join the global economy community was through an accelerated trade liberalization process. Even though the political system in force conferred public officials a wider scope of action than in other parts of the world, domestic industrialists - who were used to operating under a protectionist system - were determined to resort to all their political power to stop the liberalization process. It was in this context that contingent trade protection institutions were born.

The analysis offered in this chapter clearly reveals that the creation of institutions related to contingent trade protection mechanisms served the fundamental purpose of supporting the new economic model of trade opening. Mexican public officials were fully aware of protectionist abuses often committed by institutions of this kind in other countries and were determined not to create "a back door to protectionism." in Mexico. Therefore, new administration units were

\footnotetext{
$82 \quad$ Paragraph 193, op. cit.

83 Paragraphs 221 to 228, op. cit.
} 
established, their distinct feature being their highly professional culture, aiming at a clearly unbiased conduct. Systems in other parts of the world were studied and sound methodologies were applied. The future of the trade liberalization process depended partly on how successful the government could be in convincing domestic producers of the fact that serious institutions would defend them against unfair international competitors. However, local manufacturers also had to understand that the newly created institutions were not meant to provide unjustified protection.

The strengthening of institutions as well as of the legal structure of the contingent protection system took place at the time the NAFTA was being negotiated. It is important to underscore that most procedures and methods adopted by Mexican institutions resulted from the public officials' interest, as mentioned before, in creating sound and reliable structures for administering these protection policies. The pressure exerted by Mexico's trade partners was not the key reason to account for the legal and institutional reforms introduced in that period.

Table 11 - Number of Tariff Items Subject to Antidumping Duties in 2002

\begin{tabular}{||c|c|c||}
\hline Investigated countries & $\begin{array}{c}\text { Number of tariff items } \\
\text { investigated }\end{array}$ & $\begin{array}{c}\text { Percentage of total tariff } \\
\text { items }\end{array}$ \\
\hline China & 1,317 & $96.27 \%$ \\
\hline United States & 19 & $1.39 \%$ \\
\hline Russia & 10 & $0.73 \%$ \\
\hline Korea & 9 & $0.66 \%$ \\
\hline Brazil & 7 & $0.51 \%$ \\
\hline Ukraine & 7 & $0.51 \%$ \\
\hline Denmark & 5 & $0.37 \%$ \\
\hline Taiwan & 5 & $0.37 \%$ \\
\hline France & 4 & $0.29 \%$ \\
\hline 10 countries & 3 & $2.19 \%$ \\
\hline 3 countries & 2 & $0.44 \%$ \\
\hline 4 countries & 1 & $0.29 \%$ \\
\hline Total tariff items subject to duties & 1,368 & Not applicable* \\
\hline \hline
\end{tabular}

Source: Based on data from the World Trade Atlas and the 2002 Antidumping Agreement.

The figures in Tables 11 and 12 serve to assess the actual impact of contingent protection mechanisms on current trade flows in Mexico. Most products affected by antidumping duties come from China; 96\% of tariff items currently subject to antidumping duties are of Chinese origin (see Table 11 below). Nevertheless, when assessing the global impact of such duties on Mexican imports, it is worth noting that Mexican authorities have succeeded in not using these 
mechanisms as indiscriminate protection tools, since their application has affected less than $1 \%$ of the country's total imports (see Table 12 below).

Table 12 - Estimation of Mexican Total Trade Affected by Antidumping or Safeguard Measures, 2002

\begin{tabular}{||l|c|c|c||}
\hline \multicolumn{1}{|c|}{ Countries } & $\begin{array}{c}\text { Total imports per } \\
\text { country of origin } \\
\text { (USD million) }\end{array}$ & $\begin{array}{c}\text { Imports of items } \\
\text { subject to } \\
\text { antidumping duties } \\
\text { (USD million) }\end{array}$ & $\begin{array}{c}\text { Percentage of imports } \\
\text { from the country of } \\
\text { origin }\end{array}$ \\
\hline 1. China & 6,274 & 600.44 & $9.5697 \%$ \\
\hline 2. Ukraine & 83 & 1.68 & $2.0078 \%$ \\
\hline 3. Hong Kong & 509 & 7.74 & $1.5201 \%$ \\
\hline 4. Russia & 236 & 2.18 & $0.9239 \%$ \\
\hline 5. United States & 106,557 & 890.25 & $0.8355 \%$ \\
\hline 6. Denmark & 177 & 0.74 & $0.4155 \%$ \\
\hline 7. Taiwan & 4,250 & 8.07 & $0.1899 \%$ \\
\hline 8. Korea & 3,910 & 0.97 & $0.0248 \%$ \\
\hline 9. Brazil & 2,565 & 0.05 & $0.0018 \%$ \\
\hline 10. Japan & 9,349 & 0.12 & $0.0013 \%$ \\
\hline + 17 investigated countries & & No duties in en 2002 & - \\
\hline Mexico's total imports & 168,679 & 1.512 & $0.8965 \%$ \\
\hline \hline
\end{tabular}

Source: World Trade Atlas and 2002 Antidumping Agreement.

One concern that usually arises out of the Mexican context is the adverse effect that antidumping duties and safeguard measures may have on the country's manufacturing structure. Trade liberalization had been too difficult a process to risk losing its benefits as a result of an excessive use of antidumping duties. Consequently, Mexican authorities decided to resort to several mechanisms to mitigate the negative effects of antidumping duties, particularly in the 1991-1996 period. Several cases presented in this chapter illustrate how Mexican authorities were able to apply contingent trade protection laws with a flexible criterion, so as to protect manufacturing sectors deserving protection measures while taking other national interests into account.

The discretionary application of laws on contingent trade protection is a double-edged sword. It can be beneficial when it protects certain sectors at critical moments of the trade liberalization process, but it can also degenerate into an indiscriminate protection instrument. The China Package case is a typical example of how antidumping duties can be applied to support the opening of trade, while it also unveils its potential for discretionary use. In the 
spring of 1993, the financial situation of domestic manufacturers was difficult indeed import volumes were increasing fast, and voices against trade liberalization were being raised more and more. This was most untimely, since the Mexican government was embarked in defining the NAFTA's fate a few months ahead. Mexico needed to reach the end of such a process with a widespread consensus in favor of furthering trade liberalization and high credibility on the new contingent protection mechanisms. The China Package case is likely to have contributed to building such consensus. In other words, this certain degree of flexibility in the application of antidumping rules lent its support to the general opening of the Mexican economy.

In addition, the Mexican case serves to illustrate another advantage of creating strong institutions against unfair competition. In this field, as in soccer, a strong offensive is the best defense. When highly-qualified staff members are recruited and trained to administer laws to protect domestic manufacturers against unfair competition, the government is also training officials to help domestic exporters in proceedings initiated against them in other countries. At the time of the creation of the UPCI, one of its explicitly stated functions was to advise Mexican exporters involved in investigations of unfair practice and safeguard measures in foreign countries. On the other hand, the international experience shows that one of the most effective ways to deter foreign manufacturers from filing requests for unfair practice investigations in their own countries is to face them with the implicit and potential risk of being involved in such investigations themselves as exporters in another country.

Mexico is one of the emerging economies with the vastest experience in applying contingent trade protection laws. The success of these laws as tools to support trade liberalization is beyond any doubt. Mexican authorities realized that there was only one chance to get these institutions right and deemed it important to provide them with solid foundations from the very start. As the old saying goes, “A child who grows up without discipline can't be straightened out later."

The WTO multilateral agreements on antidumping and safeguard proceedings are still weak. Current regulations allow for the abuse of these measures as protectionist tools. Mexico created relatively solid institutions, but the lack of more accurate rules, specific methodologies, and strict procedures in the WTO agreements open up the possibility for 
Mexico to change the way it has administered these protection mechanisms so far. The changes in the staff and priorities that follow any change of government might gravely undermine originally serious institutions. The most effective way to prevent such institutions from degenerating is through a multilateral agreement that should impose strict discipline on all WTO members.

\section{Bibliography}

Arriola, Carlos, editor, Testimonios sobre el TLC, Ed. Diana, Grupo Editorial Miguel Ángel Porrúa, Mexico, 1994.

Arriola ,Carlos (1994). Documentos básicos del TLCAN, SECOFI, Mexico 1994.

Gabinete de Comercio Exterior (1986). El Proceso de Adhesión de México al Acuerdo General sobre Aranceles Aduaneros y Comercio (GATT), United Mexican States, August 7, 1986.

Leycegui, Beatriz (2000). “Acordar para disentir: la solución de controversias en el Tratado de Libre Comercio de América del Norte,” in ¿Socios Naturales? Cinco años del Tratado de Libre Comercio de América del Norte, Leycegui and Fernández de Castro (coordinators), January 2000, ITAM and Grupo Editorial Miguel Ángel Porúa.

Miranda, Jorge (1995). “Análisis económico de la forma en que México ha venido aplicando las leyes de prácticas desleales de comercio internacional de 1987 a 1995,” in Comercio a Golpes: Las prácticas desleales de comercio internacional bajo el TLCAN, Leycegui, Robson and Stein, coordinators, Grupo Editorial Miguel Ángel Porrúa, $1^{\text {st }}$ Spanish edition, October 1997.

Ramos Tercero, Raúl (1995). "Prácticas Desleales de Comercio Internacional y Medidas de Emergencia”, El Mercado de Valores, Issue 11, November 1995, Mexico.

Reyes de la Torre, Luz Elena (1995). "Metodología para evaluar el impacto de las importaciones en condiciones de dumping sobre la industria nacional: la experiencia mexicana”, in Prácticas desleales de comercio internacional, UNAM, Mexico City. 
SECOFI (1990). “Ley Reglamentaria del Artículo 131 de la Constitución Política de los

Estados Unidos Mexicanos en Materia de Comercio Exterior,” in Sistema Mexicano de Defensa Contra Prácticas Desleales de Comercio Internacional, Cuadernos SECOFI, Serie Comercio Exterior, Mexico, F.D. 1990.

SECOFI (1990). "Reglamento contra prácticas desleales de comercio internacional,” in Sistema Mexicano de Defensa Contra Prácticas Desleales de Comercio Internacional, Cuadernos SECOFI, Serie Comercio Exterior, Mexico, F.D. 1990.

SECOFI (1993). Tratado de Libre Comercio con América del Norte, Official text, Miguel Ángel Porrúa Grupo Editorial, December 1993, Mexico, F.D.

SECOFI (1994). Documentos básicos del TLCAN, Carlos Arriola (compiler), October 1994.

SECOFI (1995). Programa de Política Industrial y Comercio Exterior (PROPICE), Mexico, F.D.

SECOFI (1997). Informe de Labores de la UPCI 1991-1996, El Sistema Mexicano de Defensa contra Prácticas Desleales de Comercio Internacional, Mexico, F.D.

Secretaría de Economía (2003). Informe de Labores de la UPCI 2000, El Sistema Mexicano de Defensa contra Prácticas Desleales de Comercio Internacional, Mexico, F.D.

Serra Puche, Jaime, (1994). "Informe del Secretario de comercio y Fomento Industrial a la Comisión de Comercio de la Honorable Cámara de Senadores, sobre la reciprocidad internacional a la apertura económica de México, 7 de julio de 1994,” in Documentos básicos del TLCAN, Carlos Arriola (compiler), SECOFI, October 1994

Serra Puche, Jaime y Espinosa Velasco J., Enrique (2004). "Diez años del Tratado de Libre Comercio de América del Norte,” in El Nuevo Milenio Mexicano, Pascual García Alba, Lucino Gutiérrez and Gabriela Torres (Coordinators), Mexico, F.D. 2004.

Zabludovsky, Jaime (1994). “El proceso de Negociación del Tratado de Libre Comercio de América del Norte,” in Testimonios sobre el TLC, Carlos Arriola (1994) (compiler). 
Zabludovsky, Jaime (1989). Trade Liberalization and Macroeconomic Adjustment in Mexico, 1983-1988, May 1989.

Diario Oficial de la Federación (1987 to 2003). All determinations involving antidumping proceedings.

Diario Oficial de la Federación (2002). “Acuerdo que identifica las fracciones arancelarias de la Tarifa de la Ley de los Impuestos Generales de Importación y Exportación, en las cuales se clasifican las mercancías cuya importación está sujeta al pago de cuotas compensatorias,” Mexico, F.D. March 25 ${ }^{\text {th }}, 2002$. 


\section{Statistical Appendix}

Table 1. Investigations by country -product initiated in Mexico 1987-2003

\begin{tabular}{|c|c|c|c|c|c|}
\hline No. & Product & Country & Type of investigation & $\begin{array}{l}\text { Initiation } \\
\text { Resolution }\end{array}$ & $\begin{array}{c}2002 \\
\text { Effective } \\
\text { Quota } \\
\end{array}$ \\
\hline 1 & Caustic Soda & U.S. & Antidumping & 29-Jan-87 & \\
\hline 2 & Triethylamine & Germany & Antidumping & 09-Mar-87 & \\
\hline 3 & & U.S. & Antidumping & 09-Mar-87 & \\
\hline 4 & Monoisopropylamine & U.S. & Antidumping & 10-Jul-87 & \\
\hline 5 & Watthourmeters & U.S. & Antidumping & 10-Jul-87 & \\
\hline 6 & Orbit magazine & U.S. & Antidumping & 10-Jul-87 & \\
\hline 7 & Kraft board & U.S. & Antidumping & 24-Aug-87 & \\
\hline 8 & Monoethyl ether acetate & U.S. & Antidumping & 22-Sep-87 & \\
\hline 9 & Silicon carbide & Brazil & Antidumping & 22-Sep-87 & \\
\hline 10 & Potassium carbonate & U.S. & Antidumping & 23-Sep-87 & \\
\hline 11 & & Belgium & Antidumping & 23-Sep-87 & \\
\hline 12 & & Germany & Antidumping & 23-Sep-87 & \\
\hline 13 & Potassium hydroxide & U.S. & Antidumping & 23-Sep-87 & \\
\hline 14 & & Belgium & Antidumping & 23-Sep-87 & \\
\hline 15 & & Germany & Antidumping & 23-Sep-87 & \\
\hline 16 & Artificial brown corundum & Brazil & Antidumping & 23-Sep-87 & \\
\hline 17 & Monoethylamine & U.S. & Antidumping & 04-Dec-87 & \\
\hline 18 & Graphite electrodes & Spain & Antidumping & 21-Dec-87 & \\
\hline 19 & ATT microcomputers & U.S. & Antidumping & 07-Jan-88 & \\
\hline 20 & Vat blue & U.S. & Antidumping & 11-Jan-88 & \\
\hline 21 & & Germany & Antidumping & 11-Jan-88 & \\
\hline 22 & Urethral sounds & Malaysia & Antidumping & 18-Feb-88 & \\
\hline 23 & Toluene dissocyanate & U.S. & Antidumping & 10-Aug-88 & \\
\hline 24 & Steel bars & Brazil & Antidumping & 15-Sep-88 & \\
\hline 25 & Steel bands & Brazil & Antidumping & 15-Sep-88 & \\
\hline 26 & Steel products & $\begin{array}{c}\text { European } \\
\text { Community }\end{array}$ & Antidumping & 21-Sep-88 & \\
\hline 27 & Ball bearings and screws & Japan & Antidumping & 02-Dec-88 & \\
\hline 28 & Cellophane films & U.S. & Antidumping & 09-Dec-88 & \\
\hline 29 & $\begin{array}{l}\text { Kitchenware made of iron } \\
\text { and/or die-cast steel and glazed } \\
\text { porcelainized steel (pewter) }\end{array}$ & Taiwan & Antidumping & 08-Dec-88 & \\
\hline 30 & Sorbitol & France & Antidumping & 13-Mar-89 & $\mathrm{X}$ \\
\hline 31 & Vat blue & Brazil & Antidumping & 12-Apr-89 & \\
\hline 32 & Alkaline batteries & U.S. & Antidumping & 12-Apr-89 & \\
\hline 33 & Dampers & Brazil & Antidumping & 04-Sep-89 & \\
\hline 34 & \begin{tabular}{|l|} 
Acrylic fibers \\
\end{tabular} & U.S. & Antidumping & 25-Sep-89 & \\
\hline 35 & \begin{tabular}{|l|} 
Rubber thread \\
\end{tabular} & Spain & Antidumping & 09-Oct-89 & \\
\hline 36 & Ceramic tiles for walls & Brazil & Antidumping & 29-Dec-89 & \\
\hline 37 & PVC & U.S. & Antidumping & 06-Feb-90 & $\mathrm{X}$ \\
\hline
\end{tabular}




\begin{tabular}{|c|c|c|c|c|c|}
\hline No. & Product & Country & Type of investigation & $\begin{array}{l}\text { Initiation } \\
\text { Resolution }\end{array}$ & $\begin{array}{c}2002 \\
\text { Effective } \\
\text { Quota } \\
\end{array}$ \\
\hline 38 & Denim & U.S. & Antidumping & 31-May-90 & \\
\hline 39 & & Hong Kong & Antidumping & 31-May-90 & $\mathrm{X}$ \\
\hline 40 & 2 ethyl hexanol & U.S. & Antidumping & 05-Sep-90 & \\
\hline 41 & Kraft board & U.S. & Antidumping & 11-Sep-90 & \\
\hline 42 & Aluminum ingot & Venezuela & Countervailing Duty & 08-Nov-90 & \\
\hline 43 & Diiyodohydroxyquinoline & India & Antidumping & 10-Nov-90 & \\
\hline 44 & Corrugated rod & U.S. & Antidumping & 28-Nov-90 & $\mathrm{X}$ \\
\hline 45 & & Venezuela & Antidumping & 28-Nov-90 & $\mathrm{X}$ \\
\hline 46 & Steel sheet in rolls & U.S. & Antidumping & 30-Nov-90 & \\
\hline 47 & Hot rolled sheet & U.S. & Antidumping & 30-Nov-90 & \\
\hline 48 & Cold rolled sheet & U.S. & Antidumping & 30-Nov-90 & \\
\hline 49 & Vinyl floor covering in rolls & U.S. & Antidumping & 20-Mar-91 & \\
\hline 50 & Regenerated cellulose tubes & U.S. & Antidumping & 23-May-91 & \\
\hline 51 & & Spain & Antidumping & 23-May-91 & \\
\hline 52 & Dishware & China & Antidumping & 23-May-91 & $\mathrm{X}$ \\
\hline 53 & Cationic starch & Netherlands & Antidumping & 29-Jul-91 & \\
\hline 54 & Plastic syringes & U.S. & Antidumping & 29-Jul-91 & \\
\hline 55 & Wire rod & U.S. & Antidumping & 20-Sep-91 & \\
\hline 56 & Telephone connectors & U.S. & Antidumping & 28-Oct-91 & \\
\hline 57 & Electric power transformers & Brazil & Antidumping & 15-Nov-91 & \\
\hline 58 & Sodium tripolyphosphate & Spain & Antidumping & 18-Feb-92 & \\
\hline 59 & Zip fasteners & Venezuela & Antidumping & 20-Feb-92 & \\
\hline 60 & Polypropylene film & Colombia & Antidumping & 20-Mar-92 & \\
\hline 61 & & Brazil & Antidumping & 20-Mar-92 & \\
\hline 62 & Malleable iron pipe fittings & China & Antidumping & 01-Apr-92 & $\mathrm{X}$ \\
\hline 63 & Short polyester fiber & South Korea & Antidumping & 07-May-92 & $\mathrm{X}$ \\
\hline 64 & Cotton and synthetic textiles & China & Antidumping & 22-May-92 & $\mathrm{X}$ \\
\hline 65 & & Taiwan & Antidumping & 22-May-92 & \\
\hline 66 & & South Korea & Antidumping & 22-May-92 & \\
\hline 67 & & Hong Kong & Antidumping & 22-May-92 & \\
\hline 68 & & Pakistan & Antidumping & 22-May-92 & \\
\hline 69 & & Argentina & Antidumping & 22-May-92 & \\
\hline 70 & & Brazil & Antidumping & 22-May-92 & \\
\hline 71 & & Colombia & Antidumping & 22-May-92 & \\
\hline 72 & $\begin{array}{l}\text { Cotton and synthetic textiles } \\
\text { and synthetic fibers }\end{array}$ & China & Antidumping & 22-May-92 & $\mathrm{X}$ \\
\hline 73 & Rubber bands & South Korea & Antidumping & 25-May-92 & \\
\hline 74 & Hot-rolled steel sheet/strip & U.S. & Antidumping & 29-May-92 & \\
\hline 75 & Cold-rolled steel sheet/strip & U.S. & Antidumping & 29-May-92 & \\
\hline 76 & Plate in coils & U.S. & Antidumping & 29-May-92 & \\
\hline 77 & Candles & China & Antidumping & 19-Jun-92 & $\mathrm{X}$ \\
\hline 78 & Christmas lighting sets & China & Antidumping & 19-Aug-92 & $\mathrm{X}$ \\
\hline 79 & Hydrogen Peroxide & U.S. & Antidumping & 08-Oct-92 & $\mathrm{X}$ \\
\hline 80 & Fluoride & China & Antidumping & 26-Nov-92 & $\mathrm{X}$ \\
\hline 81 & Coated flat steel & U.S. & Antidumping & 24-Dec-92 & \\
\hline 82 & Plate in sheets & U.S. & Antidumping & 24-Dec-92 & \\
\hline
\end{tabular}




\begin{tabular}{|c|c|c|c|c|c|}
\hline No. & Product & Country & Type of investigation & $\begin{array}{l}\text { Initiation } \\
\text { Resolution }\end{array}$ & $\begin{array}{c}2002 \\
\text { Effective } \\
\text { Quota }\end{array}$ \\
\hline 83 & Padlocks & China & Antidumping & 24-Dec-92 & $\mathrm{X}$ \\
\hline 84 & Bovine meat & $\begin{array}{c}\text { European } \\
\text { Community }\end{array}$ & Antidumping & 05-Mar-93 & $\mathrm{X}$ \\
\hline 85 & & $\begin{array}{l}\text { European } \\
\text { Community }\end{array}$ & Countervailing Duty & 05-Mar-93 & $\mathrm{X}$ \\
\hline 86 & Zip fasteners & Colombia & Antidumping & 05-Mar-93 & \\
\hline 87 & $\begin{array}{l}\text { Polystyrene (crystal and } \\
\text { impact) }\end{array}$ & U.S. & Antidumping & 05-Mar-93 & \\
\hline 88 & & Germany & Antidumping & 05-Mar-93 & \\
\hline 89 & Swine & U.S. & Antidumping & 05-Mar-93 & \\
\hline 90 & Certain steels & Brazil & Antidumping & 05-Apr-93 & \\
\hline 91 & $\begin{array}{l}\text { Automobile electric antennae } \\
\text { and parts }\end{array}$ & Brazil & Antidumping & 05-Apr-93 & \\
\hline 92 & Grey Portland cement & Venezuela & Antidumping & 08-Apr-93 & \\
\hline 93 & Toys & China & Antidumping & 14-Apr-93 & $\mathrm{X}$ \\
\hline 94 & $\begin{array}{l}\text { Waterproof rubber or plastic } \\
\text { footwear }\end{array}$ & China & Antidumping & 15-Apr-93 & $\mathrm{X}$ \\
\hline 95 & $\begin{array}{l}\text { Other rubber or plastic } \\
\text { footwear }\end{array}$ & China & Antidumping & 15-Apr-93 & $\mathrm{X}$ \\
\hline 96 & Leather footwear & China & Antidumping & 15-Apr-93 & $\mathrm{X}$ \\
\hline 97 & Certain textile footwear & China & Antidumping & 15-Apr-93 & $\mathrm{X}$ \\
\hline 98 & Other footwear and parts & China & Antidumping & 15-Apr-93 & $\mathrm{X}$ \\
\hline 99 & Bicycles & China & Antidumping & 15-Apr-93 & $\mathrm{X}$ \\
\hline 100 & Bicycle tires & China & Antidumping & 15-Apr-93 & $\mathrm{X}$ \\
\hline 101 & Bicycle inner tubes & China & Antidumping & 15-Apr-93 & $\mathrm{X}$ \\
\hline 102 & Textiles (cotton) & China & Antidumping & 15-Apr-93 & $\mathrm{X}$ \\
\hline 103 & $\begin{array}{l}\text { Textiles (other vegetable textile } \\
\text { fibers) }\end{array}$ & China & Antidumping & 15-Apr-93 & $\mathrm{X}$ \\
\hline 104 & $\begin{array}{l}\text { Textiles (synthetic or artificial } \\
\text { man-made filaments) }\end{array}$ & China & Antidumping & 15-Apr-93 & $\mathrm{X}$ \\
\hline 105 & $\begin{array}{l}\text { Textiles (synthetic or artificial } \\
\text { man-made staple filaments) }\end{array}$ & China & Antidumping & 15-Apr-93 & $\mathrm{X}$ \\
\hline 106 & Textiles (gauze) & China & Antidumping & 15-Apr-93 & $\mathrm{X}$ \\
\hline 107 & $\begin{array}{l}\text { Made-up articles (knitted } \\
\text { clothing) }\end{array}$ & China & Antidumping & 15-Apr-93 & $\mathrm{X}$ \\
\hline 108 & $\begin{array}{l}\text { Made-up articles (clothing } \\
\text { other than knitted) }\end{array}$ & China & Antidumping & 15-Apr-93 & $\mathrm{X}$ \\
\hline 109 & $\begin{array}{l}\text { Made-up articles (other made- } \\
\text { up articles) }\end{array}$ & China & Antidumping & 15-Apr-93 & $\mathrm{X}$ \\
\hline 110 & Organic chemicals & China & Antidumping & 15-Apr-93 & $\mathrm{X}$ \\
\hline 111 & Tools & China & Antidumping & 15-Apr-93 & $\mathrm{X}$ \\
\hline 112 & $\begin{array}{l}\text { Electric machines, appliances } \\
\text { and material }\end{array}$ & China & Antidumping & 15-Apr-93 & $\mathrm{X}$ \\
\hline 113 & $\begin{array}{l}\text { Recording appliances, sound } \\
\text { reproducing appliances, and TV } \\
\text { sound and image reproducing } \\
\text { appliances }\end{array}$ & China & Antidumping & $\mathrm{NE}$ & \\
\hline
\end{tabular}




\begin{tabular}{|c|c|c|c|c|c|}
\hline No. & Product & Country & Type of investigation & $\begin{array}{l}\text { Initiation } \\
\text { Resolution }\end{array}$ & $\begin{array}{c}2002 \\
\text { Effective } \\
\text { Quota } \\
\end{array}$ \\
\hline 114 & $\begin{array}{l}\text { Recreation and sports games } \\
\text { and articles }\end{array}$ & China & Antidumping & NE & \\
\hline 115 & Caustic soda & U.S. & Antidumping & 16-Apr-93 & \\
\hline 116 & Refrigerators & South Korea & Antidumping & 23-Apr-93 & \\
\hline 117 & Polypropylene homopolymer & U.S. & Antidumping & 23-Apr-93 & \\
\hline 118 & Coated flat steel & U.S. & Countervailing Duty & 30-Jun-93 & \\
\hline 119 & Cellulose & U.S. & Antidumping & 19-Jul-93 & \\
\hline 120 & Pencils & China & Antidumping & 09-Aug-93 & $\mathrm{X}$ \\
\hline 121 & Sodium carbonate & U.S. & Antidumping & 19-Aug-93 & \\
\hline 122 & Vegetable oils & EUA & Antidumping & 23-Sep-93 & \\
\hline 123 & & $\begin{array}{c}\text { European } \\
\text { Community }\end{array}$ & Antidumping & 23-Sep-93 & \\
\hline 124 & Carpets & EUA & Antidumping & 23-Sep-93 & \\
\hline 125 & Fish meal & Chile & Antidumping & 05-Oct-93 & \\
\hline 126 & Bond paper & U.S. & Antidumping & 05-Oct-93 & \\
\hline 127 & Plate in sheets & Canada & Antidumping & 27-Oct-93 & \\
\hline 128 & & Brazil & Antidumping & 27-Oct-93 & \\
\hline 129 & & U.S. & Antidumping & 27-Oct-93 & \\
\hline 130 & Hot-rolled sheet & Canada & Antidumping & $27-$ Oct-93 & \\
\hline 131 & & Brazil & Antidumping & 27-Oct-93 & \\
\hline 132 & & Venezuela & Antidumping & 27-Oct-93 & \\
\hline 133 & & South Korea & Antidumping & 27-Oct-93 & \\
\hline 134 & & Germany & Antidumping & 27-Oct-93 & \\
\hline 135 & & Netherlands & Antidumping & 27-Oct-93 & \\
\hline 136 & Cold-rolled sheet & Brazil & Antidumping & 28-Oct-93 & \\
\hline 137 & & Canada & Antidumping & 28-Oct-93 & \\
\hline 138 & & South Korea & Antidumping & 28-Oct-93 & \\
\hline 139 & & Venezuela & Antidumping & 28-Oct-93 & \\
\hline 140 & & Germany & Antidumping & 28-Oct-93 & \\
\hline 141 & & Australia & Antidumping & 28-Oct-93 & \\
\hline 142 & & U.S. & Countervailing Duty & 28-Oct-93 & \\
\hline 143 & Steel plate in rolls & Brazil & \begin{tabular}{|l|} 
Antidumping \\
\end{tabular} & 28-Oct-93 & \\
\hline 144 & & Canada & Antidumping & 28-Oct-93 & \\
\hline 145 & & South Korea & Antidumping & 28-Oct-93 & \\
\hline 146 & & Venezuela & Antidumping & 28-Oct-93 & \\
\hline 147 & & South Africa & Antidumping & 28-Oct-93 & \\
\hline 148 & & U.S. & Countervailing Duty & 28-Oct-93 & \\
\hline 149 & Valves & China & Antidumping & 01-Nov-93 & $\mathrm{X}$ \\
\hline 150 & Urea & Russian Federation & Antidumping & 08-Nov-93 & \\
\hline 151 & & Rep. of Belarus & Antidumping & 08-Nov-93 & \\
\hline 152 & & Ukraine & Antidumping & 08-Nov-93 & \\
\hline 153 & & Uzbekistan & Antidumping & 08-Nov-93 & \\
\hline 154 & & Tajikistan & Antidumping & 08-Nov-93 & \\
\hline 155 & & Lithuania & Antidumping & 08-Nov-93 & \\
\hline 156 & & Estonia & Antidumping & 08-Nov-93 & \\
\hline 157 & Gasoline additives & U.S. & Antidumping & 08-Nov-93 & \\
\hline
\end{tabular}




\begin{tabular}{|c|c|c|c|c|c|}
\hline No. & Product & Country & Type of investigation & $\begin{array}{l}\text { Initiation } \\
\text { Resolution }\end{array}$ & $\begin{array}{c}2002 \\
\text { Effective } \\
\text { Quota }\end{array}$ \\
\hline 158 & Caustic soda & U.S. & Antidumping & 08-Nov-93 & $\mathrm{X}$ \\
\hline 159 & Pencil sharpeners & China & Antidumping & 19-Nov-93 & \\
\hline 160 & Corrugated rod & Brazil & Antidumping & 29-Nov-93 & $\mathrm{X}$ \\
\hline 161 & & Spain & Antidumping & 29-Nov-93 & \\
\hline 162 & Suitcases and bags & China & Antidumping & 29-Nov-93 & \\
\hline 163 & Plywood & Indonesia & Countervailing Duty & 06-Dec-93 & \\
\hline 167 & $\begin{array}{l}\text { Commercial seamless steel } \\
\text { tubes }\end{array}$ & U.S. & Antidumping & $10-F e b-94$ & \\
\hline 168 & Wheat & U.S. & Countervailing Duty & 04-Apr-94 & \\
\hline 169 & & Canada & Countervailing Duty & 04-Apr-94 & \\
\hline 170 & Sulphuric acid & Japan & Antidumping & 15-Apr-94 & \\
\hline 171 & Bovine meat & U.S. & Antidumping & 03-Jun-94 & \\
\hline 172 & Diammonium phosphate & U.S. & Antidumping & 23-Jun-94 & \\
\hline 173 & Styrene polybutadiene & Brazil & Antidumping & 27-Oct-94 & \\
\hline 174 & Lead locks & China & Antidumping & 16-Nov-94 & $\mathrm{X}$ \\
\hline 175 & Bicycle tires & India & Antidumping & 16-Nov-94 & $\mathrm{X}$ \\
\hline 176 & Swine & Denmark & Countervailing Duty & 22-Nov-94 & \\
\hline 177 & Plate in rolls & Armenia & Antidumping & 22-Nov-94 & \\
\hline 178 & & Azerbaijan & Antidumping & 22-Nov-94 & \\
\hline 179 & & Belarus & Antidumping & 22-Nov-94 & \\
\hline 180 & & Estonia & Antidumping & 22-Nov-94 & \\
\hline 181 & & Georgia & Antidumping & 22-Nov-94 & \\
\hline 182 & & Kazakhstan & Antidumping & 22-Nov-94 & \\
\hline 183 & & Kyrgyzstan & Antidumping & 22-Nov-94 & \\
\hline 184 & & Latvia & Antidumping & 22-Nov-94 & \\
\hline 185 & & Lithuania & Antidumping & 22-Nov-94 & \\
\hline 186 & & Moldova & Antidumping & 22-Nov-94 & \\
\hline 187 & & Tajikistan & Antidumping & 22-Nov-94 & \\
\hline 188 & & Turkmenistan & Antidumping & 22-Nov-94 & \\
\hline 189 & & Ukraine & Antidumping & 22-Nov-94 & \\
\hline 190 & & Uzbekistan & Antidumping & 22-Nov-94 & \\
\hline 191 & & Russian Federation & Antidumping & 22-Nov-94 & $\mathrm{X}$ \\
\hline 192 & Fish meal & Chile & Safeguard & 30-Nov-94 & \\
\hline 193 & Iron fittings & Brazil & Antidumping & 11-Apr-95 & $\mathrm{X}$ \\
\hline 194 & Steel balls & Taiwan & Antidumping & 11-Oct-95 & \\
\hline 195 & Ammonium sulphate & U.S. & Antidumping & 07-Dec-95 & $\mathrm{X}$ \\
\hline 196 & Regenerated cellulose film & U.S. & Antidumping & 08-Dec-95 & \\
\hline 197 & Gasoline additives & U.S. & Antidumping & 31-May-96 & \\
\hline 198 & Baby carriages & Taiwan & Antidumping & 31-May-96 & $\mathrm{X}$ \\
\hline 199 & & China & Antidumping & 31-May-96 & $\mathrm{X}$ \\
\hline 200 & Furazolidone & China & Antidumping & 17-Oct-96 & $\mathrm{X}$ \\
\hline 201 & High fructose corn syrup & U.S. & Antidumping & 27-Feb-97 & \\
\hline 202 & Apples & U.S. & Antidumping & 06-Mar-97 & $\mathrm{X}$ \\
\hline 203 & Peaches & Greece & Antidumping & 26-May-97 & \\
\hline 204 & & Greece & Countervailing Duty & 26-May-97 & \\
\hline 205 & Cut bond paper & U.S. & Antidumping & 27-May-97 & $\mathrm{X}$ \\
\hline
\end{tabular}




\begin{tabular}{|c|c|c|c|c|c|}
\hline No. & Product & Country & Type of investigation & $\begin{array}{l}\text { Initiation } \\
\text { Resolution }\end{array}$ & $\begin{array}{c}2002 \\
\text { Effective } \\
\text { Quota }\end{array}$ \\
\hline 206 & Plate in sheets & Russian Federation & Antidumping & 23-Jul-97 & $\mathrm{X}$ \\
\hline 207 & & Ukraine & Antidumping & 23-Jul-97 & $\mathrm{X}$ \\
\hline 208 & Gas lighters & China & Antidumping & 20-Mar-98 & $\mathrm{X}$ \\
\hline 209 & Cold-rolled sheet & Russia & Antidumping & 20-Mar-98 & $\mathrm{X}$ \\
\hline 210 & & Kazakhstan & Antidumping & 20-Mar-98 & $\mathrm{X}$ \\
\hline 211 & & Bulgaria & Antidumping & 20-Mar-98 & $\mathrm{X}$ \\
\hline 212 & Crystal polystyrene & U.E. & Antidumping & 10-Jun-98 & \\
\hline 213 & $\begin{array}{l}\text { Synthetic iron and steel oxide } \\
\text { \& iron hydroxide }\end{array}$ & U.S. & Antidumping & 30-Jun-98 & \\
\hline 214 & Swine for slaughter (live) & U.S. & Antidumping & 21-Oct-98 & $\mathrm{X}$ \\
\hline 215 & Bovine meat and edible offal & E. U. A. & Antidumping & 21-Oct-98 & $\mathrm{X}$ \\
\hline 216 & Bovine meat & U.S. & Antidumping & 21-Oct-98 & \\
\hline 217 & Urea & E. U.A. & Antidumping & 14-Dec-98 & $\mathrm{X}$ \\
\hline 218 & & Russia & Antidumping & 14-Dec-98 & \\
\hline 219 & Hot-rolled sheet & Russia & Antidumping & 25-Jan-99 & $\mathrm{X}$ \\
\hline 220 & & Ukraine & Antidumping & 25-Jan-99 & \\
\hline 221 & Methyl parathion & Denmark & Antidumping & 22-Feb-99 & $\mathrm{X}$ \\
\hline 222 & $\begin{array}{l}\text { Synthetic polybutadiene } \\
\text { styrene rubber }\end{array}$ & U.S. & Antidumping & 08-Mar-99 & \\
\hline 223 & Impact polystyrene & E. U. A. & Antidumping & 10-Mar-99 & \\
\hline 224 & Seamless steel tubes & Japan & Antidumping & 13-May-99 & $\mathrm{X}$ \\
\hline 225 & Portable mechanic typewriters & China & Antidumping & 25-May-99 & \\
\hline 226 & Iron or non-alloy steel wire rod & Ukraine & Antidumping & 27-Jul-99 & $\mathrm{X}$ \\
\hline 227 & Electric transformers & Brazil & Antidumping & 11-Nov-99 & \\
\hline 228 & $\begin{array}{l}\text { Polyester filament, textile } \\
\text { texturized }\end{array}$ & Korea & Antidumping & 22-Dec-99 & $\mathrm{X}$ \\
\hline 229 & & Taiwan & Antidumping & 22-Dec-99 & $\mathrm{X}$ \\
\hline 230 & Acrylic fiber & Spain & Antidumping & 19-Apr-00 & \\
\hline 231 & & Turkey & Antidumping & 19-Apr-00 & \\
\hline 232 & & Chile & Antidumping & 19-Apr-00 & \\
\hline 233 & Refrigerators & Korea & Antidumping & 11-Sep-00 & \\
\hline 234 & Long grain milled rice & U.S. & Antidumping & 11-Dec-00 & $\mathrm{X}$ \\
\hline 235 & Trichloroisocyanuric acid & China & Antidumping & 23-Mar-01 & $\mathrm{X}$ \\
\hline 236 & $\begin{array}{l}\text { Galvanized hexagonal steel } \\
\text { wire mesh }\end{array}$ & China & Antidumping & 05-Jul-01 & $\mathrm{X}$ \\
\hline 237 & Steel beams & Brazil & Antidumping & 05-Jul-01 & $\mathrm{X}$ \\
\hline 238 & Standard tubing & Guatemala & Antidumping & 24-Aug-01 & \\
\hline 239 & $\begin{array}{l}\text { Ethylene glycol } \\
\text { monobutyl ether }\end{array}$ & U.S. & Antidumping & 14-Dec-01 & \\
\hline 240 & $\begin{array}{l}\text { Ceramic dishware and loose } \\
\text { parts }\end{array}$ & Colombia & Antidumping & 21-Jan-02 & \\
\hline 241 & & Ecuador & Antidumping & 21-Jan-02 & \\
\hline 242 & & Indonesia & Antidumping & 21-Jan-02 & \\
\hline 243 & High carbon ferro-manganese & China & Antidumping & 08-May-02 & \\
\hline 244 & Steel chain with welded links & China & Antidumping & 10-May-02 & \\
\hline 245 & Seamless steel tubes & Taiwan & Antidumping & 14-May-02 & \\
\hline 246 & Ferro-silico-manganese & Ukraine & Antidumping & 15-May-02 & \\
\hline
\end{tabular}




\begin{tabular}{|c|c|c|c|c|c|}
\hline No. & Product & Country & Type of investigation & $\begin{array}{l}\text { Initiation } \\
\text { Resolution }\end{array}$ & $\begin{array}{c}2002 \\
\text { Effective } \\
\text { Quota } \\
\end{array}$ \\
\hline 247 & $\begin{array}{l}\text { Glazed ceramic floor and wall } \\
\text { tiles }\end{array}$ & Spain & Antidumping & 16-Мay-02 & \\
\hline 248 & Plywood & Rest of the world & Safeguard & 15-Aug-02 & \\
\hline 249 & Carbon steel line pipe & Russia & Antidumping & 18-Oct-02 & \\
\hline 250 & & Rumania & Antidumping & 18-Oct-02 & \\
\hline 251 & Chicken leg quarters & U.S. & Safeguard & 27-Nov-02 & \\
\hline 252 & Pork products & U.S. & Antidumping & 7-Jan-03 & \\
\hline 253 & $\begin{array}{l}\text { Carbon steel connections for } \\
\text { butt welding }\end{array}$ & China & Antidumping & 4-Apr-03 & \\
\hline 254 & $\begin{array}{l}\text { Partially hydrogenated fatty } \\
\text { acid }\end{array}$ & U.S. & Antidumping & 6-Jun-03 & \\
\hline 255 & Virgin and refined olive oil & $\begin{array}{c}\text { European } \\
\text { Community }\end{array}$ & Countervailing Duty & 16-Jul-03 & \\
\hline 256 & Hydrogen peroxide & U.S. & Antidumping & 17-Jul-03 & \\
\hline 257 & Concrete steel nails & China & Antidumping & 24-Jul-03 & \\
\hline 258 & Carbon steel line pipe & U.S. & Antidumping & 29-Aug-03 & \\
\hline 259 & Triple-pressed stearic acid & U.S. & Antidumping & 6-Nov-03 & \\
\hline 260 & Newsprint & Canada & Antidumping & 25-Nov-03 & \\
\hline 261 & & U.S. & Antidumping & 25-Nov-03 & \\
\hline 262 & Sodium hexameta-phosphate & China & Antidumping & 6-Dec-03 & \\
\hline
\end{tabular}

